TECTONICS, VOL. 6, NO. 2, PAGES 151-173, APRIL 1987

\section{GEOLOGIC FRAMEWORK, TECTONIC EVOLUTION, AND DISPLACEMENT HISTORY OF THE ALEXANDER TERRANE}

George E. Gehrels ${ }^{1}$ and Jason B. Saleeby

Division of Geological and Planetary Sciences, California Institute of Technology, Pasadena
Devonian (Klakas orogeny). The second phase is marked by Middle Devonian through Lower Permian strata which accumulated in tectonically stable marine environments. Devonian and Lower Permian volcanic rocks and upper Pennsylvanian-Lower Permian syenitic to dioritic intrusive bodies occur locally but do not appear to represent major magmatic systems. The third phase is marked by Triassic volcanic and sedimentary rocks which are interpreted to have formed in a rift environment. Previous syntheses of the displacement history of the terrane emphasized apparent similarities with rocks in the Sierra-Klamath region and suggested that the Alexander terrane evolved in proximity to the California continental margin during Paleozoic time. Our studies indicate, however, that the geologic record of the Alexander terrane is quite different from that in the Sierra-Klamath region, and we conclude that the two regions were not closely associated during Paleozoic time. The available geologic, paleomagnetic, and paleontologic data are more consistent with a scenario involving (1) early Paleozoic origin and evolution of the Alexander terrane along the paleo-Pacific margin of Gondwana, (2) rifting from this margin during Devonian time, (3) late Paleozoic migration across the paleo-Pacific basin in low southerly paleolatitudes, (4) residence in proximity to the paleo-Pacific margin of South America during latest Paleozoic(?)-Triassic time, and (5) Late Permian(?)-Triassic rifting followed by northward displacement along the eastern margin of the Pacific basin. 


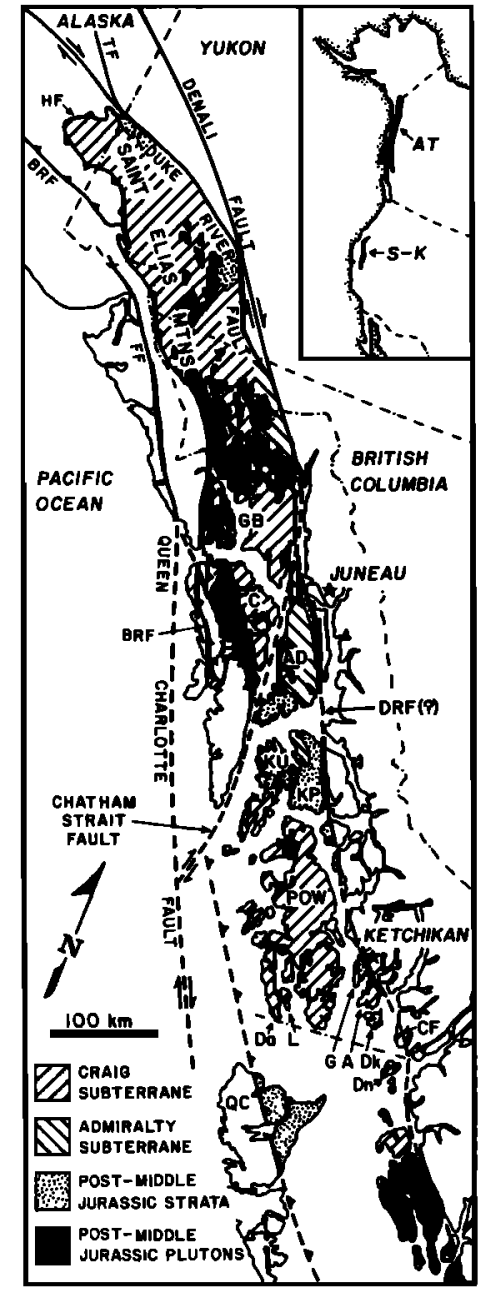

Fig. 1. Location map of the Alexander terrane showing regions and features referred to in the text. Adapted from Monger and Berg (1984), Tipper et al. (1981), Yorath and Chase (1981), MacKevett (1978), Campbell and Dodds (1982a, b, c, 1983a, b), and Gehrels and Berg (1984). Location Map: TF, Totschunda fault; HF, Hubbard fault; BRF, Border Ranges fault; FF, Fairweather fault, DRF, Duke River fault. GB, Glacier Bay; C, Chichagof Island, AD, Admiralty Island; $\mathrm{KU}$, Kuiu Island; KP, Kupreanof Island; POW, Prince of Wales Island; G, Gravina Island; A, Annette Island; Dk, Duke Island; Da, Dall Island; L, Long Island; Dn, Dundas Island; CF, Cape Fox area; QC, Queen Charlotte Islands. Inset Map: AT, Alexander terrane; S-K, Sierra-Klamath region.

\section{INTRODUCTION}

The Alexander terrane is a tectonic fragment that underlies much of southeastern (SE) Alaska, the Saint Elias Mountains of eastern Alaska, Yukon Territory, and British Columbia, and part of the coastal region of west-central British Columbia (Figure 1). The terrane is anomalous in the North American Cordillera in that it has an exceptionally long and complete geologic record: Rocks are known from every Paleozoic epoch except the Late Permian and perhaps the Early Cambrian. In addition, rocks of late Proterozoic(?)-Cambrian, Late Triassic, and Middle(?) Jurassic age occur locally. Upper Jurassic to mid-Cretaceous strata and Cretaceous intrusive bodies overlie and intrude rocks belonging to the Alexander and adjacent terranes.

Rocks of the Alexander terrane were initially described as a distinct geologic assemblage by Schuchert (1923), who suggested that they belong to a geosynclinal system (the "Alexandrian embayment") which was isolated from the main Cordilleran geosyncline. Based on their occurrence outboard of the Cordilleran miogeocline, Wilson (1968) hypothesized that these rocks constitute a distinct tectonic fragment which is exotic to North America. Berg et al. (1972) named this fragment the Alexander terrane, described its primary geologic components, and delineated its boundaries with adjacent terranes.

We have conducted detailed field and $\mathrm{U}-\mathrm{Pb}$ (zircon) geochronologic studies in southern SE Alaska and have reviewed the work of others to the north and south in an effort to reconstruct the geologic and tectonic evolution of the Alexander terrane. In this report, we describe its geologic framework and tectonic evolution and discuss constraints and speculations on its displacement history.

\section{GEOLOGIC FRAMEWORK}

\section{Overview}

The Alexander terrane was subdivided by Berg et al. (1978) and Monger and Berg (1984) into the Craig, Annette, and Admiralty subterranes based on apparent differences in their geologic records. Rocks in most regions belong to the Craig subterrane, which consists of upper Proterozoic(?)-Cambrian to Middle(?) Jurassic rocks. Annette, Gravina, and Duke islands and regions to the southeast have been assigned to the Annette subterrane, which is distinguished from the Craig subterrane based on apparent dissimilarities in the Devonian and older rocks and on the absence of upper Paleozoic strata. Our mapping demonstrates, however, that Devonian and older rocks in the two subterranes are quite similar and that upper Paleozoic strata are also absent in adjacent parts of the Craig subterrane (Gehrels et al., 
1987). In addition, mapping by Woodsworth and Orchard (1985) in the Dundas Island region

(Figure 1) indicates that upper Paleozoic strata do occur locally in the Annette subterrane. We therefore assign the Triassic and older rocks in the Annette, Gravina, Duke, and Dundas islands region to the Craig subterrane and recommend that the term "Annette subterrane" be abandoned.

The Admiralty subterrane (Figure 1) is distinguished from the Craig subterrane on the basis of apparent differences in their Carboniferous and older rocks. Similarities in Permian and Triassic strata of the Admiralty and Craig subterranes indicate that the two subterranes have been closely associated since at least Early Permian time (Berg et al., 1978). Discussion of the geology of the Admiralty subterrane and comparison with the geology of other regions are hampered by the lack of detailed geologic studies in pre-Permian rocks of the Admiralty subterrane. Because of this lack of information, the following discussion focuses on rocks belonging to the Craig subterrane.

Southern Alexander Terrane (Figures 2 and 3)

Pre-Middle Ordovician metamorphic rocks. The oldest rocks recognized in the Alexander terrane consist of greenschist- and locally amphibolite-facies metavolcanic and metasedimentary rocks of the Wales metamorphic suite (Buddington and Chapin, 1929; Gehrels and Saleeby, 1987). These rocks were derived from basaltic to andesitic pillow flows, breccia, and tuff; rhyolitic breccia and tuff; and graywacke, mudstone, and thick limestone layers. Most rocks have a foliation and lineation along which protolith features are strongly flattened, isoclinally folded, and elongated. Late- to post-metamorphic structures include (1) shallow-plunging upright folds with wavelengths up to several kilometers, (2) outcrop-scale asymmetric folds that are apparently parasitic to the upright folds, and (3) steeply plunging kilometer-scale folds which deform the other fold sets.

Rocks of the Wales suite are locally intruded by small bodies of penetratively deformed metadiorite and metagranodiorite which yield $\mathrm{U}-\mathrm{Pb}$ (zircon) apparent ages of 540 to $520 \mathrm{Ma}$ (Middle-Late Cambrian) (Gehrels et al., 1987; J.B. Saleeby, unpublished data, 1984). This minimum age constraint plus our interpretation that the dioritic-granodioritic metaplutonic rocks are genetically related to the basaltic(?)rhyolitic(?) metavolcanic rocks suggest that protoliths of the Wales suite are Cambrian and perhaps late Proterozoic in age.

Deformation and metamorphism of rocks in the Wales suite is assigned a Middle Cambrian-
Early Ordovician age because (1) Middle-Upper Cambrian metaplutonic rocks have experienced the deformation and metamorphism, (2) lessdeformed Middle Ordovician-Lower Silurian plutons intrude the Cambrian metaplutonic rocks, (3) less-deformed upper Lower and Middle Ordovician strata belonging to the Descon Formation occur near and probably overlie rocks of the Wales suite, and (4) metamorphic minerals in the Wales suite yield a $\mathrm{K}-\mathrm{Ar}$ isochron date of approximately $483 \mathrm{Ma}$ (Early Ordovician) (Turner et al., 1977).

Ordovician to middle Lower Silurian rocks.

Much of the southern Alexander terrane is underlain by middle(?) Lower Ordovician to middle Lower Silurian strata belonging to or correlative with the Descon Formation. These rocks include basaltic-andesitic pillow flows and breccia, rhyolitic-dacitic tuff and breccia, mudstone and graywacke turbidites, and subordinate limestone, conglomerate, and shale. The volcanic rocks were apparently erupted from submarine volcanic centers, and volcaniclastic strata were probably deposited in basins adjacent to these centers. Although the basal contact of the Descon Formation has nowhere been identified, we suspect that it was originally an unconformity based on the greater degree of deformation and metamorphism of the Wales suite, and the occurrence of a thick sedimentary breccia at the base(?) of the Descon Formation on southern Prince of Wales Island (Herreid et al., 1978).

A regionally extensive intrusive suite was emplaced in the southern Alexander terrane during deposition of the Descon Formation. Major rock types include hornblende diorite; biotite-hornblende granodiorite, leucogranodiorite, and quartz diorite; hornblende-biotite quartz monzonite; subordinate hornblende gabbro, biotite granite and quartz syenite; and minor hornblendite and clinopyroxenite. Our $\mathrm{U}-\mathrm{Pb}$ geochronologic data indicate that most diorite and granodiorite bodies (unit Odg on Figure 2) are Middle Ordovician in age and that quartz diorite, quartz monzonite, granite, and quartz syenite bodies (unit OSq on Figure 2) are Late Ordovician-Early Silurian in age. These intrusive rocks are interpreted to be genetically related to basaltic-rhyolitic rocks of the Descon Formation based on their similarity in composition and age and on observed gradations from intrusive bodies, through swarms of dikes and hypabyssal bodies, into the volcanic rocks (Gehrels and Saleeby, 1986, 1987).

On east-central Prince of Wales Island, Middle Ordovician-Lower Silurian diorite and quartz diorite locally intrude Cambrian metaplutonic rocks (Gehrels et al., 1987). This 


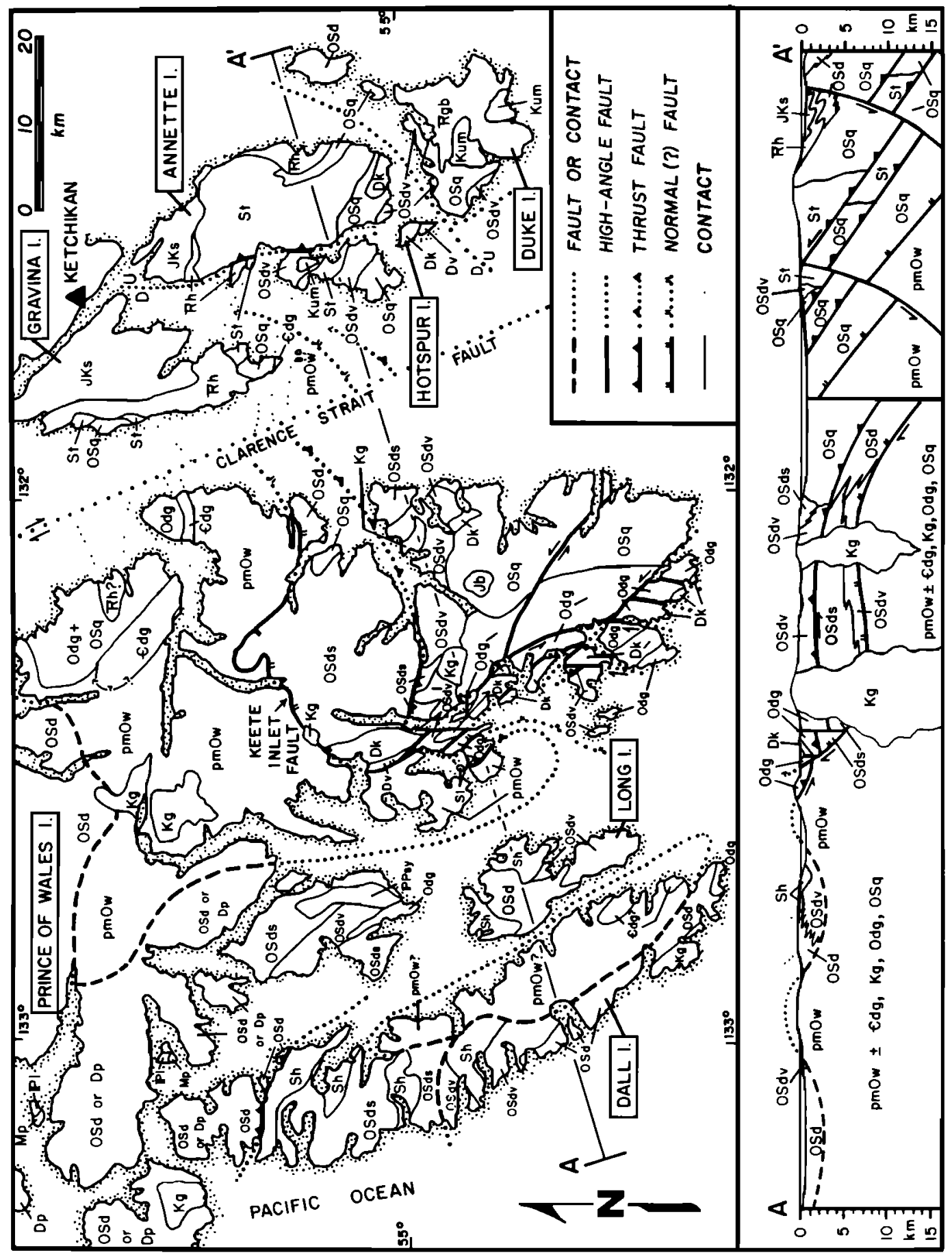




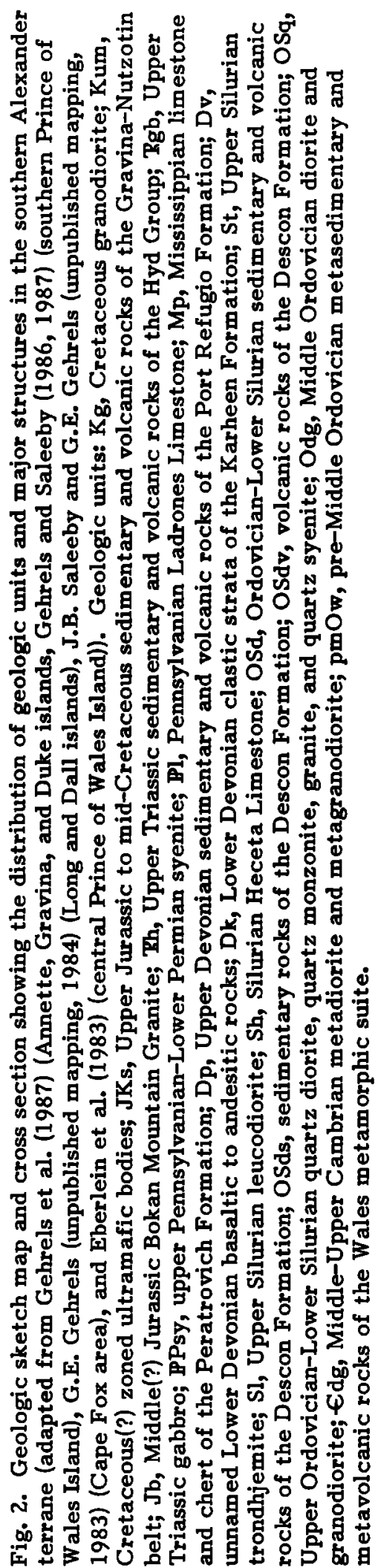

critical intrusive relationship demonstrates that the pre-Middle Ordovician metamorphic complex served as basement to at least part of the Ordovician-Lower Silurian volcanicplutonic-sedimentary assemblage.

Upper Lower and Upper Silurian rocks. Silurian strata conformably overlie rocks of the Descon Formation on much of north-central Prince of Wales Island and locally on Dall and Long islands. These strata consist of shallowmarine limestone of the Heceta Limestone, thick sections of turbidites belonging to or correlative with the Bay of Pillars Formation, and conglomerate layers and lenses (Muffler, 1967; Eberlein and Churkin, 1970; Eberlein et al., 1983; Brew et al., 1984; Ovenshine and Webster, 1970; G.E. Gehrels, unpublished mapping, 1984). The shallow-marine limestone was apparently deposited on or adjacent to Descon-age volcanic centers after the main phase of magmatic activity, and the turbidites and conglomeratic strata record uplift and erosion of the older volcanic-plutonicsedimentary complex (Brew et al., 1966; Eberlein et al., 1983).

The Silurian strata on north-central Prince of Wales Island pinch out toward the southeast and are not seen in the Annette, Gravina, Duke, and southern Prince of Wales islands region. Rather, to the southeast, large trondhjemite plutons and small leucodiorite bodies (containing aegirine-augite, arfvedsonite, and melanite(?) garnet) are the only upper Lower or Upper Silurian rocks recognized. These intrusive rocks are significantly different in composition and mineralogy from the Ordovician-Lower Silurian intrusive rocks and were emplaced approximately $15 \mathrm{~m} . \mathrm{y}$. after the youngest known member of the earlier suite.

Lower Devonian strata. Lower Devonian rocks in the southern Alexander terrane generally consist of fining-upward clastic strata which overlie Silurian and older rocks on a regional unconformity. In most areas these strata are referred to as the Karheen Formation. On southern Prince of Wales Island, Lower Devonian strata include conglomeratic red beds and subordinate sedimentary breccia at the base, siltstone, mudstone, and limestone in the middle, and laminated mudstone and black shale at the top of the section (Gehrels and Saleeby, 1986, 1987). These strata are locally overlain by and interbedded with basalticdacitic volcanic rocks. The unconformity at the base of the section combined with facies relations and sedimentary structures suggests that the conglomeratic strata were deposited in topographically rugged, subaerial to shallowmarine environments. Subsidence of the region 


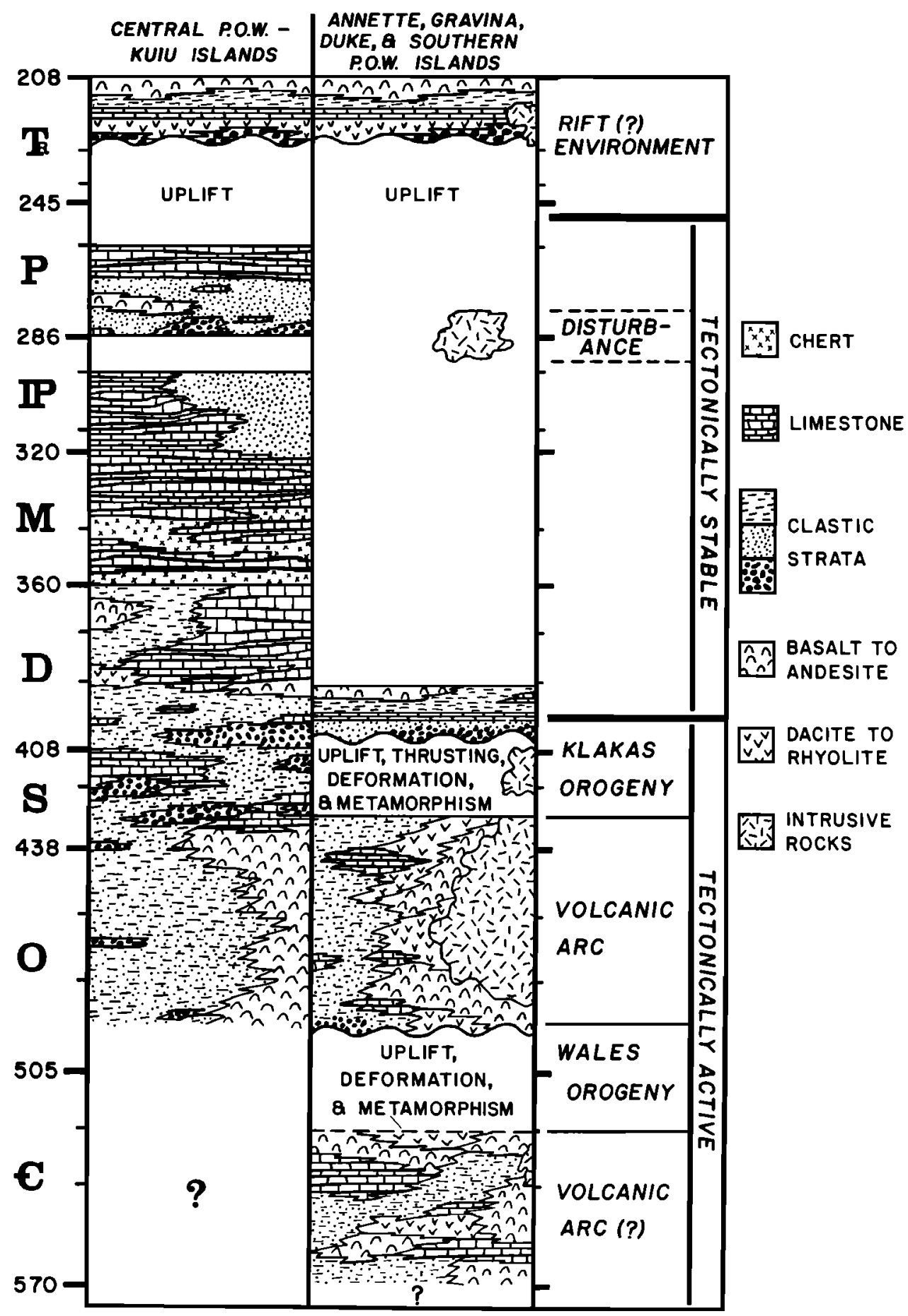

Fig. 3. Schematic columns depicting the geologic and tectonic evolution of the Alexander terrane in southern SE Alaska (adapted from Eberlein et al. (1983), Brew et al. (1984), Gehrels and Saleeby $(1986,1987)$, and Gehrels et al. (1987)). The geologic time scale is from Palmer (1983). 
is recorded by superjacent shallow-marine limestone overlain by graptolitic shale. On Annette and Hotspur islands, Lower Devonian strata include shallow marine limestone, fine-grained clastic strata, olistostromal layers, conglomerate, and superjacent basaltic-andesitic volcanic rocks (Gehrels et al., 1987). The occurrence of clasts of Silurian metadiorite and trondhjemite in conglomeratic strata records uplift and erosion of pre-Devonian rocks prior to deposition of the Karheen Formation.

Strata belonging to or correlative with the Karheen Formation on central Prince of Wales Island consist of conglomeratic red beds, finergrained clastic strata, and subordinate limestone (Eberlein and Churkin, 1970; Eberlein et al., 1983; Ovenshine, 1975). As described by Ovenshine et al. (1969), these strata become thicker and coarser grained to the south and contain paleocurrent indicators which record northwest directed transport. These workers interpret the Karheen Formation as part of a subaerial to shallow marine clastic wedge that was derived from uplifted regions to the southeast. The coarse clastic strata on southern Prince of Wales Island were apparently deposited near the source region for this clastic wedge.

Upper Paleozoic rocks. Upper Paleozoic rocks occur in restricted areas of central Prince of Wales Island and the Dundas Island region (Figure 1). On central Prince of Wales Island, regionally significant post-Karheen rocks consist of basaltic volcanic rocks (Coronados Volcanics) and limestone (Wadleigh Limestone) of Middle and Late Devonian age, Upper Devonian clastic strata and volcanic rocks (Port Refugio Formation), Mississippian shallowmarine limestone and chert (Peratrovich Formation), and Pennsylvanian shallow-marine limestone (Ladrones Limestone) and clastic strata (Klawak Formation) (Eberlein and Churkin, 1970; Eberlein et al., 1983) (Figures 2 and 3). These strata are not recognized on southern Prince of Wales Island or on Annette, Gravina, and Duke islands, but some units reappear to the southeast. According to Woodsworth and Orchard (1985), Mississippian limestone in the Dundas Island region resembles the upper part of the Peratrovich Formation, and Pennsylvanian limestone and siltstone resemble the Klawak Formation.

Upper Triassic rocks. Upper Triassic volcanic and sedimentary rocks of the Hyd Group occur on Annette and Gravina islands (Gehrels et al., 1987), in the Dundas Island region (Woodsworth and Orchard, 1985), and perhaps on east-central Prince of Wales Island (Buddington and Chapin, 1929, p. 313). On
Annette and Gravina islands, the base of the section is marked by a regional unconformity overlain by a discontinuous but locally thick section of coarse, poorly sorted, massive polymictic conglomerate and breccia which we interpret to represent a submarine talus breccia. These conglomeratic strata grade upsection into several hundred meters of rhyolite and rhyolitic tuff, which are conformably overlain by up to $100 \mathrm{~m}$ of thickbedded to massive limestone. Several hundred meters of calcareous siltstone and thin-bedded limestone overlie the massive limestone and grade upsection into a thick sequence of basaltic flows and breccia. Upper Triassic strata in the Dundas Island region include limestone, clastic strata, basalt-andesite, and rhyolite which unconformably overlie upper Paleozoic strata (Woodsworth and Orchard, 1985).

Bokan Mountain Granite (Middle(?) Jurassic). The Bokan Mountain Granite is a Middle(?) Jurassic peralkaline ring-dike complex on southern Prince of Wales Island that consists of aegirine- and arfvedsonite-bearing granite, aplite, porphyry, and pegmatite (Gehrels and Saleeby, 1986, 1987). This intrusive body is apparently the youngest component of the Alexander terrane, as similar bodies have not been recognized in adjacent terranes.

Faults of the southern Alexander terrane. The oldest faults recognized are southwest vergent thrust faults which moved between earliest Silurian and middle Early Devonian time. These faults have been mapped on Annette Island (where they are overprinted by younger high-angle faults) and on southern Prince of Wales Island, and may form the contact between Ordovician-Silurian strata and pre-Middle Ordovician metamorphic rocks on Dall Island (Figure 2).

A variety of faults were active after deposition of the Lower Devonian strata and prior to mid-Cretaceous time. Crosscutting relations on southern Prince of Wales Island indicate that right-lateral, north to northeast striking faults displace Devonian strata and are cut by a complex set of curviplanar, northwest striking faults with left-lateral displacement. These faults are in turn cut by the Keete Inlet fault, which is locally intruded by midCretaceous plutons. The Keete Inlet fault regionally juxtaposes Ordovician through Devonian strata over pre-Middle Ordovician rocks of the Wales metamorphic suite. Its curviplanar nature and regional younger over older juxtaposition lead us to the tentative conclusion that the fault is an extensional structure with significant east-side-down(?) displacement. 
Central and Northern Alexander Terrane

Rocks north of the Prince of Wales Island region have been mapped and described most recently by Brew et al. (1984) on Kuiu, Kupreanof, and northern Prince of Wales islands, Loney et al. (1975) on Chichagof Island, Lathram et al. (1965) on Admiralty Island, Brew et al. (1978) and Brew and Ford (1985) in the Glacier Bay region, and Campbell and Dodds (1982a, b, c, 1983a, b) in the Saint Elias Mountains (Figure 1). The geologic map and unit descriptions of Gehrels and Berg (1984) summarize the geologic relations in SE Alaska and, together with the maps and descriptions of Campbell and Dodds, serve as the basis for the following discussion.

Cambrian through Devonian rocks. North of the Prince of Wales Island region in SE Alaska, Silurian turbidites (similar to the Bay of Pillars Formation) and shallow-marine limestone (similar to the Heceta Limestone) are the oldest rocks exposed. Subjacent rocks include Silurian and older(?) trondhjemitic and metamorphic rocks on northeastern Chichagof Island (Loney et al., 1975) and perhaps Ordovician argillite, chert, and limestone belonging to the Admiralty subterrane (Hood Bay Formation) on Admiralty Island (Lathram et al., 1965). Lower Devonian strata include finergrained components of the Karheen Formation on north central Prince of Wales Island

(Ovenshine et al., 1969; Ovenshine, 1975; Eberlein et al., 1983); some or all of the conglomeratic strata belonging to the Cedar Cove Formation on northeastern Chichagof Island (Loney et al., 1975); and fine-grained marine clastic strata and limestone (unnamed units and part of the Rendu Formation) near Glacier Bay. These strata are overlain by limestone, clastic strata, and volcanic rocks of Middle and Late Devcnian age on Chichagof Island and in the Glacier Bay region. Contacts between the various Devonian units are gradational or conformable where known, except on northeastern Chichagof Island where Upper Devonian volcanic rocks (Freshwater Bay Formation) are separated from adjacent units by unconformities.

In the Saint Elias Mountains, lower Paleozoic rocks include basaltic to andesitic volcanic rocks, volcaniclastic strata, limestone, and gabbro of Cambrian age, and a thick, widespread, and apparently continuous section of Ordovician through Upper Devonian-lower Mississippian limestone and marine clastic strata. Poorly known sedimentary, volcanic, and metamorphic rocks in some parts of the Saint Elias region may also be of early Paleozoic age.
Mississippian through Permian rocks. In SE Alaska, upper Paleozoic strata include Mississippian limestone, chert, and subordinate gypsum (Iyoukeen Formation on Chichagof Island), Pennsylvanian limestone and chert (part of the Saginaw Bay Formation on Kuiu Island), and Lower Permian limestone (Pybus Formation), marine clastic strata, and subordinate basaltic volcanic rocks and conglomerate (Halleck Formation) (KuiuKupreanof islands and in the Glacier Bay region). Upper Paleozoic rocks in the Saint Elias Mountains include large syentitic and dioritic bodies of late Pennsylvanian-Early Permian age in the northwestern part of the terrane, and a poorly known but apparently widespread section of argillite, shale, siltstone, sandstone, and limestone.

Upper Triassic strata. Upper Triassic strata occur along the northeastern margin of the terrane in SE Alaska and are known only locally but may be widespread in the Saint Elias Mountains. In SE Alaska the strata are everywhere separated from subjacent Lower Permian and older rocks by an unconformity and generally resemble the rocks on Annette and Gravina islands (Gehrels et al., 1986). Upper Triassic strata in the Saint Elias Mountains include limestone, marine clastic strata, basaltic volcanic rocks, and perhaps conglomerate and felsic volcanic rocks.

\section{TECTONIC EVOLUTION}

Late Proterozoic(?)-Cambrian Through Early Devonian Time

The initial phase in the evolution of the Alexander terrane is characterized by late Proterozoic(?)-Cambrian through Early Devonian magmatic and and orogenic activity in the southern part of the terrane and by Cambrian volcanism in the Saint Elias Mountains. General compositional similarities between the upper Proterozoic(?)-Cambrian volcanic and intrusive rocks in the terrane and igneous rocks in modern arc systems suggest that the Cambrian and older(?) rocks may have formed in a volcanic arc environment. This interpretation has been stated by Churkin (1974), Churkin and Eberlein (1977), and others but is difficult to demonstrate because of the regional metamorphism of rocks in the Wales metamorphic suite and the lack of detailed studies of rocks in the Saint Elias Mountains.

In SE Alaska, these arc-type(?) rocks were penetratively deformed, regionally metamorphosed, uplifted, and eroded during a Middle Cambrian-Early Ordovician tectonic 


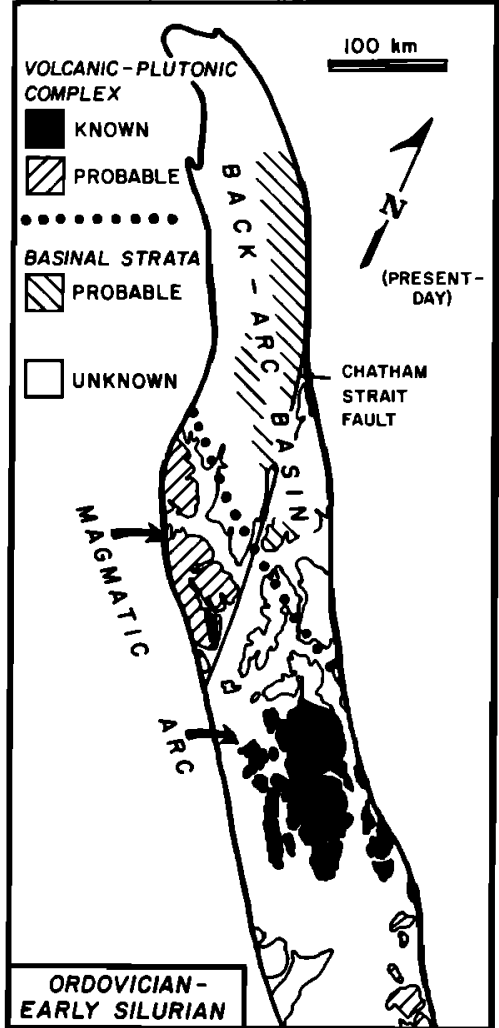

Fig. 4. Sketch map showing the interpreted distribution of tectonic elements in the Alexander terrane during Ordovician-Early Silurian time. We have restored $150 \mathrm{~km}$ of right-lateral displacement on the Chatham Strait fault (Hudson et al., 1981).

event which we refer to as the Wales orogeny (Gehrels and Saleeby, 1984). Structures associated with this event record regional shortening, but it is not known whether the tectonism occurred in response to interplate or intraplate processes.

Volcanism, plutonism, and sedimentation resumed soon after the Wales orogeny in $\mathrm{SE}$ Alaska and continued until approximately middle Early Silurian time. Rocks formed during this period were interpreted by Monger et al. (1972), Churkin (1974), and many others to have formed in a volcanic arc environment based on their lithic similarity to rocks in young and presently active volcanic-plutonic systems. This interpretation is supported by our major, minor, and trace element geochemical studies of Ordovician volcanic and plutonic rocks from Prince of Wales Island (conducted with Fred Barker) (Gehrels and Saleeby, 1987). We interpret the arc system to have trended northwesterly across the present north northwest elongation of the terrane (Figure 4) based on (1) trends of Silurian facies, (2) alignment of regions with Ordovician-Silurian plutonic and/or volcanic rocks (after restoring $150 \mathrm{~km}$ of dextral offset on the Chatham Strait fault) (Hudson et al., 1981), and (3) trends of structures that formed during Silurian-Early Devonian time. We speculate that the arc system faced to the southwest because Ordovician-Lower Silurian shallow-marine strata extend for a large distance northeast of the volcanic-plutonic complex (Figure 4).

The arc-type magmatism in the southern Alexander terrane ceased during middle Early Silurian time in response to the onset of a middle Silurian-earliest Devonian tectonic event which we refer to as the Klakas orogeny (Gehrels et al., 1983). Buddington and Chapin (1929, p. 281-289) originally recognized this tectonic disturbance as an unconformity separating Devonian strata from Silurian and older rocks. Brew et al. (1966) recognized that the disturbance is also recorded by SilurianDevonian conglomeratic strata on Prince of Wales, Kuiu, and Chichagof islands. More detailed studies of these conglomeratic strata led Ovenshine et al. (1969) to suggest that Lower Devonian conglomerate on central Prince of Wales Island formed as part of a clastic wedge which represents a "basinward manifestation of Late Silurian to pre-Middle Devonian diastrophism in southern southeastern Alaska." Loney et al. (1975, p. 92) reported that similar conglomeratic strata on northeastern Chichagof Island were shed from a subaerial source area to the southwest and suggested that uplift of the source area began during Silurian time.

Our studies indicate that the Klakas orogeny is manifest on Annette, Gravina, Duke, and southern Prince of Wales islands by (1) cessation of the Ordovician-Lower Silurian volcanism and plutonism, (2) emplacement of compositionally distinct Upper Silurian leucodiorite and trondhjemite bodies, (3) southwest-vergent movement on thrust faults during middle Silurian-earliest Devonian time, (4) deposition and deformation of a Lower Devonian talus breccia adjacent to some thrust faults, (5) greenschist and locally amphibolite-facies metamorphism of Ordovician-Lower Silurian rocks in some areas, (6) regional structural uplift (5-10 $\mathrm{km}$ in some areas) during middle Silurian-earliest Devonian time, and (7) deposition of Lower Devonian conglomeratic red beds (Karheen Formation) in topographically rugged alluvial to shallow-marine environments (Gehrels and Saleeby, 1987; Gehrels et al., 1987). Genetic relations between the Klakas orogeny and the Upper Silurian trondhjemite and leucodiorite bodies are uncertain. The 


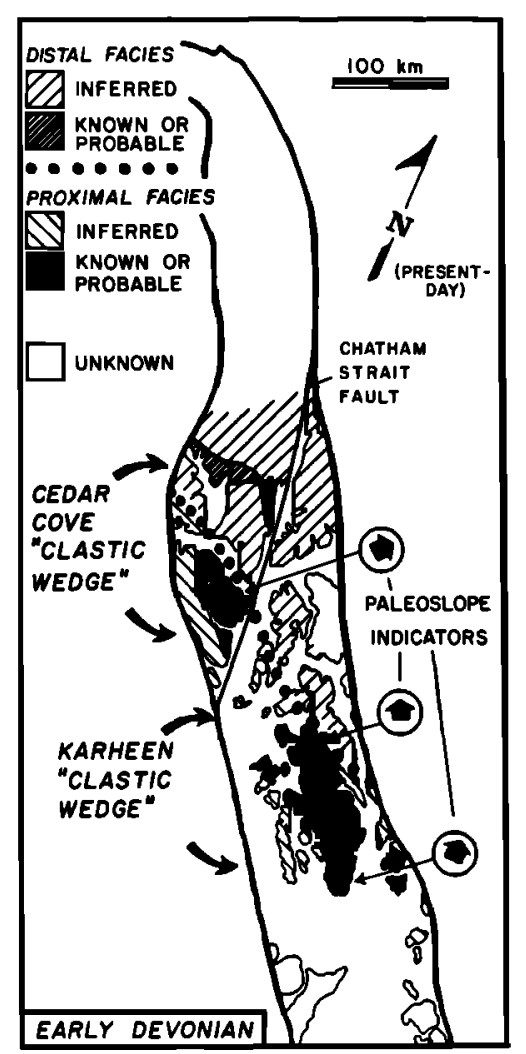

Fig. 5. Sketch map showing the interpreted distribution of tectonic elements in the Alexander terrane during Early Devonian time. We have restored $150 \mathrm{~km}$ of right-lateral displacement on the Chatham Strait fault (Hudson et al., 1981).

compositional difference between these rocks and the Ordovician-Lower Silurian intrusive bodies, combined with their emplacement during or soon after the main phase of deformation, metamorphism, and thrusting, suggest that they may be anatectic in origin rather than part of the older magmatic arc suite.

The Klakas orogeny is recognized in the central Prince of Wales Island region by the (1) Lower Devonian conglomeratic strata described by Ovenshine et al. (1969), (2) thick layers and lenses of polymictic conglomerate in upper Lower and Upper Silurian limestone and turbidites, and (3) southward pinchout of the Silurian strata. Clasts in the Silurian and Devonian conglomerates include limestone, chert, graywacke, basalt-andesite, gabbro, diorite, granite, and syenite (Eberlein and Churkin, 1970; Ovenshine and Webster, 1970; Brew et al., 1984). The plutonic clasts were probably eroded from volcanic-plutonic complexes to the south and southeast, and locally, perhaps, from syenitic sources on northeastern Chichagof Island (prior to movement on the Chatham Strait fault).

The Lower Devonian strata of SE Alaska record the location of regions uplifted during the Klakas orogeny and also record regional subsidence following the main orogenic phase. We suggest that the conglomeratic strata in the Prince of Wales Island region and on northeastern Chichagof Island are near-source or proximal facies of the Karheen clastic wedge and the Cedar Cove clastic wedge, which may have been contiguous prior to displacement on the Chatham Strait fault (Figure 5). More distal facies of these wedges may be represented by fine-grained marine clastic strata of probable Early Devonian age in the Glacier Bay area and perhaps in the Saint Elias Mountains region. Middle Lower and Middle Devonian limestone and fine-grained marine clastic strata which overlie the conglomeratic strata indicate that the orogenic activity ceased and that the region subsided below sea level soon after earliest Devonian time.

The structural and stratigraphic relations described above indicate that deformation during the Klakas orogeny was predominantly compressional, although regional extension during later phases of the orogeny is not precluded by the field relations. As with the Wales orogeny, we are not yet able to demonstrate whether the Klakas orogeny occurred in response to interplate (i.e., collisional) processes along a convergent plate boundary or to intraplate processes following a phase of volcanic arc activity.

\section{Middle Devonian Through Early Permian Time}

The tectonic evolution from Middle Devonian through Early Permian time is difficult to reconstruct with certainty because strata of this age occur in relatively restricted areas of SE Alaska and have not been studied in detail in the Saint Elias Mountains. Upper Paleozoic strata which have been studied, however, generally accumulated in tectonically stable shallow-marine environments.

Widespread Middle Devonian and Lower Permian limestone and dolomite record phases of tectonic stability throughout much of the terrane, and areally restricted upper Lower and Upper Devonian, lower and upper Mississippian, and lower and middle Pennsylvanian carbonates record stability in at least some regions during much of late Paleozoic time. Devonian volcanic rocks with local unconformities, upper Pennsylvanian-Lower Permian dioritic to syenitic bodies, and Lower Permian volcanic rocks and conglomerate record tectonic activity 
in some areas, but these phases of tectonic activity appear to have been more restricted in time and space than the early Paleozoic phases.

We conclude that the Alexander terrane evolved in a tectonically stable environment, perhaps as part of an oceanic microcontinent in an intraplate environment, during much of late Paleozoic time based on the (1) long period (approximately $130 \mathrm{~m} . y$. ) of relative tectonic stability, (2) deposition of shallow-marine limestone during much of late Paleozoic time (Figure 3), and (3) scarcity of coarse clastic strata and regional unconformities. What tectonic activity is recorded may have been extensional in origin, in contrast to the early Paleozoic compressional events.

\section{Late Permian and Triassic Time}

The third phase in the tectonic evolution of the Alexander terrane is recorded by a regional unconformity separating Upper Triassic strata from Lower Permian and older rocks and by various characteristics of the Triassic strata. The Upper Triassic strata and their subjacent unconformity are interpreted to have formed during a Late Permian(?)-Triassic rifting event based on the (1) occurrence of a thick section of Triassic marine strata in the central Saint Elias Mountains which MacIntyre (1984) interprets to have been deposited in a rift basin, (2) restriction of Upper Triassic strata to a belt along the eastern margin of the terrane in SE Alaska, (3) bimodal (basalt-rhyolite) composition of the volcanic rocks in SE Alaska, (4) lack of regional metamorphism and (or) deformation associated with the Late Permian(?)-Triassic uplift and erosion, and (5) presence of Upper Triassic talus breccia and thick lenses of conglomerate (Gehrels et al., 1986, 1987). Normal(?) movement on the Keete Inlet fault (south-central Prince of Wales Island) and emplacement of steeply dipping mafic dikes in much of the southern part of the terrane may also have occurred during this extensional phase.

The occurrence of a rift(?) assemblage along the eastern margin of the terrane suggests that Paleozoic rocks may have extended for a considerable distance northeast of the present extent of the terrane prior to Late Triassic time and that Jura-Cretaceous strata of the Gravina belt (Berg et al., 1972) accumulated in this rifted basin.

\section{DISPLACEMENT HISTORY}

A variety of geologic, paleomagnetic, and paleobiogeographic evidence indicates that the
Alexander terrane has been displaced considerable distances from where it evolved during Paleozoic time. We have attempted to reconstruct its displacement history primarily through comparisons of its geologic and tectonic evolution with the history recorded in other regions. Such attempts are aided by the long, complete, and well-preserved geologic record of the Alexander terrane, by the availablity of paleomagnetic data for much of its history, and, to a lesser degree, by the reported similarities of fossils from the terrane and fossils from other regions.

Recognizing regions which were at one time associated with the Alexander terrane is difficult because (1) there is considerable variation in the geology of the terrane along its length and across its width, (2) large regions of the terrane have not been studied in detail, (3) there is little evidence that the terrane ever evolved on or in proximity to a continental landmass, and (4) many Paleozoic orogenic belts have not been studied in detail and/or have been overprinted by younger tectonism. The implications of such associations are also uncertain because potentially correlative rocks in other regions may also have been displaced from their previous positions. Such correlative regions must exist, however, if we are correct in our interpretations that the OrdovicianLower Silurian magmatic arc trended at an oblique angle across the present elongation of the Alexander terrane and that the terrane may have been considerably larger prior to Late Permian(?)-Triassic rifting.

\section{Geologic Constraints}

The geologic framework described in previous sections serves as the primary tool in identifying regions with which the Alexander terrane may have been associated. Specific characteristics, such as upper Proterozoic(?)Cambrian and Ordovician-Lower Silurian magmatic suites, Silurian trondhjemitic rocks of anatectic(?) origin, widespread Silurian turbidites, shallow-marine carbonate, and conglomerate, and Lower Devonian red beds serve as fingerprints for comparison with other regions. The interpreted tectonic evolution of the terrane also offers criteria for comparison. In particular, phases of Middle Cambrian-Early Ordovician and middle Silurianearliest Devonian orogenic activity, late Paleozoic tectonic stability, and Late Permian(?)-Triassic rifting(?) place general constraints on the history of potentially associated regions. 
TABLE 1. Palecmagnetic data from the Alexander terrane

\begin{tabular}{|c|c|c|c|c|}
\hline \multirow[t]{2}{*}{ Time } & \multirow[t]{2}{*}{ Paleolat itude } & \multicolumn{3}{|c|}{$\begin{array}{l}\text { Sense and Amount of Rotation } \\
\text { (Relative to the Paleopole) }\end{array}$} \\
\hline & & $\begin{array}{l}\text { Nor thern } \\
\text { Hemi sphere }\end{array}$ & $\begin{array}{l}\text { Sout } \\
\text { Hemi }\end{array}$ & $\begin{array}{l}\text { thern } \\
\text { sphere }\end{array}$ \\
\hline Late Triassic ${ }^{a}$ & $44^{\circ} \pm 10^{\circ}$ & $125^{\circ} \mathrm{c}$-cwise & $55^{\circ}$ & cwi se \\
\hline Early Permian ${ }^{b}$ & $9^{\circ} \pm 8^{\circ}(?)$ & $152^{\circ}$ cwise (?) & $28^{\circ}$ & c-cwise (?) \\
\hline Pennsylvanian ${ }^{c}$ & $8^{\circ} \pm 7^{\circ}$ & $80^{\circ}$ c-cwise & $100^{\circ}$ & cwise \\
\hline Mississippian ${ }^{c}$ & $14^{\circ} \pm 8^{\circ}$ & $85^{\circ}$ c-cwise & $95^{\circ}$ & cwise \\
\hline Late Devonianc & $21^{\circ} \pm 6^{\circ}$ & $82^{\circ} \mathrm{c}$-cwise & $98^{\circ}$ & cwise \\
\hline Middle Devonianc & $10^{\circ} \pm 5^{\circ}$ & $67^{\circ} \mathrm{c}$-cwise & $113^{\circ}$ & cwise \\
\hline Late Ordovicianc & $7^{\circ} \pm 8^{0}$ & $62^{\circ} \mathrm{c}-\mathrm{cwise}$ & $115^{\circ}$ & cwise \\
\hline Middle Ordovicianc & $1^{\circ} \pm 19^{\circ}$ & $103^{\circ} \mathrm{c}$-cwise & $77^{\circ}$ & cwise \\
\hline
\end{tabular}

Definitions: cwise, clockwise rotation since deposition of strata; c-cwise, counter-clockwise rotation.

Data Sources: ${ }^{2}$ Hillhouse and Grome (1980); b Panuska and Stone (1985); C Van der Voo et al. (1980).

\section{Paleomagnetic Constraints}

Paleomagnetic studies have been conducted on rocks of Ordovician, Devonian, Mississippian, Pennsylvanian (Van der Voo et al., 1980), Permian (Panuska and Stone, 1985), and Triassic age (Hillhouse and Gromme, 1980) from the southern Alexander terrane. Table 1 summarizes the results of these studies, showing the apparent paleolatitudes and the sense and amount of rotation (relative to the paleopole) required for positions in the northern and southern hemispheres. The most significant and apparently most reliable conclusion derived from these studies is that the Alexander terrane evolved in relatively low paleolatitudes (either north or south of the paleoequator) during Ordovician-Pennsylvarian time and has been displaced at least $18^{\circ}$ northward with respect to North America since Pennsylvanian time (Van der Voo et al., 1980). The significance of the Permian and Triassic data is less clear. Panuska and Stone (1985) reported that remagnetization of many samples precluded a rigorous fold test for the Permian rocks, and the moderate Late Triassic paleolatitude reported by Hillhouse and Gromme (1980) is not consistent with the low paleolatitude deduced from studies (described below) of Late Triassic bivalves.

\section{Paleobiogeographic Constraints}

Fauna and flora from the Alexander terrane have been described in many reports, but the paleobiogeographic implications of these fossils have not been synthesized. The appendix is a compilation of reported similarities of fossils from the Alexander terrane and from other regions, which we present in an effort to summarize similarities noted by others and to stimulate additional studies and discussion of the diverse and well-preserved fossils in the Alexander terrane. Although the reported similarities do not clearly identify correlatives of the Alexander terrane, they show that (1) most fossils have circum-Pacific similarities, (2) some upper Paleozoic fauna and flora are Tethyan or equatorial in affinity, and (3) Late Triassic bivalves grew in equatorial or low southerly paleolatitudes in the eastern part of the paleo-Pacific basin.

\section{Previous Hypotheses}

Evolution near its present position in the Cordillera. Churkin (1974) proposed that the Alexander terrane has not been transported northward relative to North America but has only moved toward and away from the 
continental margin during the closure and opening of marginal basins. Churkin and Eberlein (1977, p. 784) offered a more detailed scenario in which the terrane evolved as a west facing volcanic arc near its present position in the Cordillera during early Paleozoic time, switched polarity prior to or during Early Devonian time, and impinged on continental margin assemblages to the east during the Antler orogeny. These scenarios are considered unlikely because of the (1) occurrence of Permian fauna with Tethyan or equatorial affinities inboard of the terrane, (2) northward displacement of at least $18^{\circ}$ indicated by paleomagnetic data, and (3) low paleolatitude affinity of Upper Triassic bivalves in the terrane.

Evolution near western North America in proximity to rocks now in the Sierra-Klamath region. Monger and Ross (1971) and Monger et al. (1972) hypothesized that the Alexiander terrane may have evolved south of its present position near western North America based on the similarity of Permian fusulinid fauna in the Alexander terrane and in rocks inboard of the Cache Creek terrane. They postulated that the terrane was originally the southern continuation of the inboard rocks and was then displaced northward after the Cache Creek terrane had been accreted. Jones et al. (1972) suggested more specifically that the terrane was contiguous with continental-margin assemblages in the Sierra-Klamath region (central and northern California) during Paleozoic time based primarily on similarities in Silurian facies relations and Permian fusulinid faunas in the two areas.

Schweikert (1976) and Schweikert and Snyder (1981) followed this theme and hypothesized that the Alexander terrane was an east facing volcanic arc during OrdovicianSilurian time and that coeval rocks in the Sierra-Klamath region accumulated in an accretionary prism along the leading edge of this arc. They suggested that the arc magmatism migrated eastward over the older accretionary prism during Devonian time and then this composite arc collided with the western margin of North America during the Antler orogeny. According to their scenario, the Alexander terrane and rocks in the SierraKlamath region evolved in a west facing volcanic arc during late Paleozoic time, and then the Alexander terrane was displaced northward and accreted to its present position.

The hypothesis that the Alexander terrane evolved in proximity to rocks in the SierraKlamath region is consistent with the Ordovician-Pennsylvanian paleomagnetic data (Table 1). According to Van der Voo et al.
(1980), the Ordovician through Pennsylvanian paleolatitudes of the Alexander terrane are similar to a paleoposition in northeastern California-western Nevada if it is assumed that the Alexander terrane was in the northern hemisphere.

Links between the Alexander terrane and the Sierra-Klamath region have also been suggested on the basis of $\mathrm{U}-\mathrm{Pb}$ analyses of detrital zircon populations in pre-Upper Devonian rocks of the Shoo Fly Complex (Sierra Nevada Mountains). Girty and Wardlaw (1984) concluded that the zircon populations were derived during a single cycle of erosion from a source terrane containing igneous rocks of approximately $506 \pm 22 \mathrm{Ma}$ (Late CambrianEarly Ordovician). They hypothesized that the detritus was shed from the Alexander terrane based on previous suggestions that the terrane originated in the Sierra-Klamath region, the paleomagnetic evidence of Van der Voo et al. (1980), and the occurrence of lower Paleozoic igneous rocks in the Alexander terrane.

In spite of the numerous hypotheses linking the Alexander terrane with rocks of the SierraKlamath region, our studies suggest that the geologic records of the two areas are fundamentally different. The main components of potentially correlative assemblages in the Sierra-Klamath region are described by most workers as (1) ophiolitic rocks of Early Ordovician age, (2) locally to regionally disrupted Cambro(?)-Ordovician through Lower Devonian marine clastic strata and subordinate volcanic rocks and limestone, (3) Lower-Middle Devonian and subordinate Ordovician-Silurian intrusive bodies, and (4) Upper Devonian through Permian andesitic and felsic volcanic rocks, marine volcaniclastic and clastic strata, and subordinate limestone (Irwin, 1977, 1985; Potter et al., 1977; Lindsley-Griffin and Griffin, 1983; D'Allura et al., 1977; Harwood, 1983; Schweikert and Snyder, 1981). Most of these workers hypothesized that the upper Paleozoic rocks formed in a volcanic arc environment after a pre-Late Devonian orogenic event. The abundance of quartz in the lower Paleozoic strata suggests that they were deposited in proximity to a continental landmass, but there is little agreement on whether the strata formed as slope and rise deposits along a continental margin or in a volcanic arcaccretionary prism environment.

Critical differences between the two regions include the (1) presence of upper Proterozoic(?)-Cambrian arc-type(?) rocks in the Alexander terrane in contrast to the Lower Ordovician ophiolitic rocks in the SierraKlamath region, (2) lack of quartz-rich clastic strata in the Alexander terrane compared to 
their abundance in lower Paleozoic rocks of the Sierra-Klamath region, (3) intact OrdovicianLower Silurian volcanic-plutonic complex in the Alexander terrane, in contrast to the coeval sedimentary assemblages with subordinate volcanic rocks to the south, (4) timing of Paleozoic orogenic phases: Middle CambrianEarly Ordovician and middle Silurian-earliest Devonian in the Alexander terrane; post-Late Silurian and pre-Late Devonian in the Sierra Nevada (Varga and Moores, 1981; Hanson et al., 1987; Saleeby et al., 1987); probable Middle Devonian in the Klamath Mountains, and (5) abundance of upper Paleozoic arc-type volcanic rocks in the Sierra-Klamath region, in contrast to the predominant marine clastic strata and shallow-marine carbonate in the Alexander terrane.

In addition, the reported similarity of Permian fusulinid fauna from the two regions now appears to have less significance, as the distinctive fauna also occur in other regions of the circum-Pacific basin (Ross and Ross, 1983, 1985). These more recent analyses accordingly do not draw associations between the Alexander terrane and rocks in the Sierra-Klamath region during Permian time. The occurrence of Permian fusulinid faunas with Tethyan or equatorial affinities outboard of the reportedly similar rocks in the Sierra-Klamath region (Jones et al., 1972) also suggests that the Alexander terrane was located south of the Sierra-Klamath region if it was originally inboard of Cache Creek-affinity rocks.

The interpretation that the Alexander terrane was the source for detrital zircon populations of apparent Late Cambrian-Early Ordovician age in the Shoo Fly Complex (Girty and Wardlaw, 1984) is intriguingly consistent with previous scenarios, but source rocks of the appropriate composition, age, and extent have not been recognized in the Alexander terrane. Rocks which could reasonably yield zircon populations with the reported isotopic characteristics include (1) silicic metavolcanic rocks of the Wales metamorphic suite, (2) Middle Ordovician-Lower Silurian plutonic rocks containing zircons with a significant component of inherited pre-Ordovician zircon, and (3) Middle-Upper Cambrian metaplutonic layers in the Wales metamorphic suite. The silicic metavolcanic rocks are not a likely source because they are in large part or entirely preLate Cambrian in age and are very poor in zircon. The Ordovician-Lower Silurian rocks are also an unlikely source in that they are too young and do not contain detectable quantities of inherited zircon. Middle-Upper Cambrian metagranodiorite layers associated with the Wales suite yield zircon populations of nearly the appropriate age (approximately $540-520 \mathrm{Ma}$ ) (Gehrels et al., 1987), but these layers are too restricted in extent to have been a reasonable source for the sandstone described by Girty and Wardlaw (1984). Larger plutons of this age may occur beneath younger strata in other parts of the terrane, but the existence of such plutons remains speculative. More reasonable sources for the detritus described by Girty and Wardlaw (1984) are the plutons of Cambrian(?)Ordovician age in east central Idaho (Evans, 1984), which are near the interpreted source for much of the detritus in the Shoo Fly Complex (Schweikert and Snyder, 1981).

Based on the significant differences in their geologic records and the lack of other compelling arguments, we conclude that there is little evidence which links the Alexander terrane with rocks in the Sierra-Klamath region during Paleozoic time. It is possible to envision scenarios in which the two regions were adjacent to one another but have different geologic records and tectonic histories, but such scenarios remain unsupported by the present geologic data base.

Evolution in other regions. Wilson (1968), Monger and Ross (1971), and Monger et al. (1972) acknowledged the possibility that the Alexander terrane is an exotic component in the North American Cordillera but did not discuss where it may have been located prior to its Late Cretaceous-early Tertiary accretion. Our search for correlatives of the Alexander terrane focuses on early Paleozoic orogenic belts because lower Paleozoic rocks of the terrane are widespread, distinctive, and record longlived tectonic activity. We direct our search primarily to regions which were in central or southern parts of the paleo-Pacific basin based on (1) the observation that most fossils in the Alexander terrane are circum-Pacific in affinity, (2) the low paleolatitudes indicated by the paleomagnetic data of Van der Voo et al. (1980), and (3) a variety of evidence which suggests that the Alexander terrane was displaced northward after Permian time. Such evidence includes the Tethyan or equatorial affinity of Permian fusulinid fauna inboard of the Alexander terrane, the equatorial or low southerly paleolatitude recorded by Triassic bivalves (appendix), and the evidence that oceanic plates in the Pacific basin were in general moving northerly prior to and during accretion of the Alexander terrane (Engebretson et al., 1985).

According to the continental reconstructions of Scotese et al. (1979) and Scotese (1984), the paleo-Pacific basin was rimmed by continental margins of North America, South America, Antarctica, Australia, and various fragments 


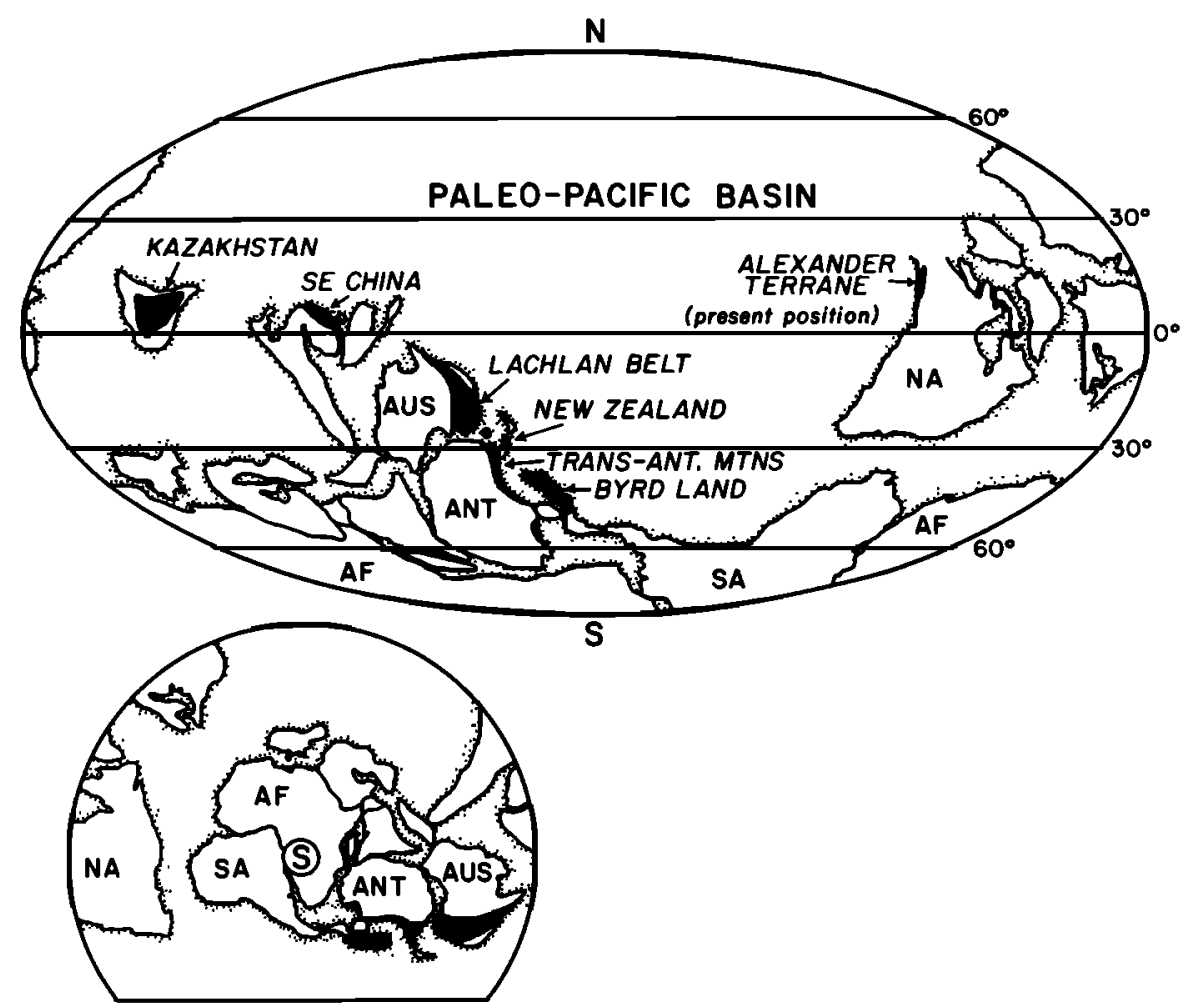

Fig. 6. Silurian continental reconstruction (from Scotese et al., 1979) showing the distribution of early Paleozoic orogenic belts along the western and southwestern margin of the paleo-Pacific basin. AUS, Australia; ANT, Antarctica; SA, South America; NA, North America; AF, Africa.

which now reside in Asia during much of early Paleozoic time (Figure 6). Along most of these continental margins there is evidence of early Paleozoic tectonic activity, and the circumPacific deformational belts of Australia, Antarctica, and South America probably all belonged to a single complex orogenic system. Because the lower Paleozoic rocks of eastern Australia have been studied in more detail than those of Antarctica or South America, our comparisons with the Alexander terrane focus on the development of the Lachlan Fold Belt of eastern Australia. Rocks in this region have recently been summarized by Cooper and Grindley (1982), Cas (1983), Veevers (1984), and Scheibner (1985) and are only briefly outlined below.

The Phanerozoic evolution of the Lachlan Belt began with the deposition of Lower and locally Middle and Upper Cambrian mafic to intermediate volcanic rocks, marine clastic strata, and subordinate limestone in western parts of the orogen. Most workers suggest that these rocks formed in a volcanic arc environment, although extensional environments are considered more likely by some. The depositional basement to these rocks locally consists of Precambrian crystalline or stratified rocks but is in most areas unknown. Beginning in Late and locally Middle Cambrian time and continuing into the Early Ordovician, these rocks were penetratively deformed, regionally metamorphosed, and intruded by syntectonic granitic plutons. This orogenic event has been referred to as the Delamerian orogeny in Australia and as the Ross orogeny in Antarctica.

Following the Middle Cambrian-Early Ordovician orogenic activity, Lower Ordovician conglomerate and quartz-rich clastic strata and Middle and Upper Ordovician shallow-marine limestone and clastic strata were deposited in the western part of the belt. These strata grade eastward into deeper water clastic strata which were deposited throughout much of the central Lathlan Belt. To the east, mafic to intermediate volcanic rocks were deposited and shallow-marine limestone accumulated in some areas. Most workers interpret these volcanic rocks as part of an east facing volcanic arc 
(referred to as the Molong arc), with the deeper water clastic strata to the west deposited in a marginal basin (Wagga trough).

The tectonic evolution of the Lachlan Belt changed dramatically with the onset of an orogenic event which began in Early Silurian time (Benambran orogeny), lasted through the middle Silurian (locally the Quidongan orogeny), and continued into Late Silurian-earliest

Devonian time (Bowning orogeny). During early phases of this orogeny, strata in the Wagga trough were regionally metamorphosed and deformed, many S-type plutons were emplaced, and large regions were uplifted above sea level and covered by terrigeneous red beds and silicic volcanic rocks. In some regions, deeper water strata were deposited in relatively narrow troughs separated by shallow-marine or terrestrial regions. The later phases of the orogeny are manifest only as uplift and erosional events. Although most manifestations of this Silurian-Early Devonian orogeny apparently record crustal shortening, some aspects suggest that regional crustal extension was also significant.

Middle Lower to upper Middle Devonian rocks occur only locally and consist of shallowmarine limestone, clastic strata, and subordinate volcanic rocks. This interval is interpreted by Cas (1983) as being transitional from a tectonically active phase during Silurian-Early Devonian time to another tectonically active phase beginning in late Middle Devonian time. The onset of the next phase of tectonism is marked by the regional Middle to Late Devonian Tabberabberan orogeny. This was followed during Late Devonian-Early Carboniferous time by widespread deposition of conglomeratic red beds and silicic and subordinate mafic volcanic rocks, and local emplacement of both S- and Itype granitic plutons. Cas (1983) suggests that these Upper Devonian-Lower Carboniferous sedimentary and bimodal volcanic rocks were deposited in an extensional environment. The final phase of regional deformation in the Lachlan Belt occurred during the midCarboniferous Kanimblan orogeny.

Evolution of the Alexander terrane along the paleo-Pacific margin of Gondwana. As presently described, rocks in the Lachlan Belt record an early Paleozoic evolution which is in many respects similar to that in the Alexander terrane. The most striking tectonic similarities are that rocks in at least some parts of the two orogens formed in a magmatic arc(?) environment during Cambrian time, were deformed during the Middle Cambrian-Early Ordovician, evolved in a volcanic arc-marginal basin regime during Ordovician time, and experienced a Silurian-Early Devonian orogenic event (Figure 7). The similarities between the two regions end in the Middle Devonian, when the Alexander terrane began to evolve in a tectonically stable environment whereas the Lachlan Belt remained tectonically active.

Our preliminary studies of other early Paleozoic orogenic belts, such as the Caledonian-Appalachian orogen, various orogens in Eurasia, and much of western South America, suggest that their geologic and tectonic evolution is significantly different from that recorded in the Alexander terrane. Many other orogens also do not satisfy the criteria of having evolved in low paleolatitudes and of having paleo-Pacific faunal affinities.

Based on the similarities with rocks in eastern Australia and previously adjacent regions of Gondwana, and dissimilarities with rocks in other regions, we raise the possibility that the Alexander terrane may have evolved in proximity to the paleo-Pacific margin of Gondwana prior to Middle Devonian time (Gehrels and Saleeby, 1984). It is not possible to identify a specific paleoposition along the margin because not enough is known about the early Paleozoic evolution of Antarctica, South America, and various fragments now residing in Asia and because the lower Paleozoic rocks presently in these orogenic belts have probably also been displaced since their formation.

Hence our hypothesis is quite general in drawing associations between the Alexander terrane and rocks along the paleo-Pacific margin of Gondwana.

The paleomagnetic data of Van der Voo et al. (1980) are consistent with a paleoposition along northern parts of the Gondwana margin if it is assumed that the terrane was in the southern hemisphere. As shown on Figure 8, the apparent paleolatitudinal position of the Alexander terrane (Van der Voo et al., 1980) is similar to that of eastern Australia (Scotese, 1984) during early Paleozoic time. The paleomagnetic data also apparently record divergence between the two regions at approximately the same time that their geologic records become dissimilar. The paleolatitudinal data therefore indicate that the Alexander terrane could have been associated with at least the northern parts of the Gondwana margin during early Paleozoic time.

Speculative Displacement History of The Alexander Terrane

Our hypothesis linking the Alexander terrane with rocks along the paleo-Pacific margin of Gondwana, combined with the paleomagnetic data (Table 1) and paleobiogeographic 


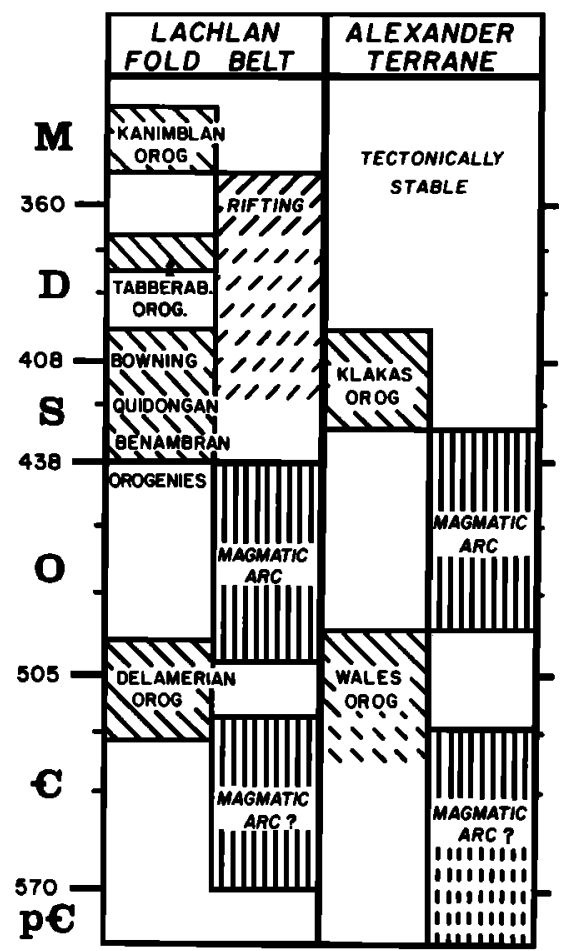

Fig. 7. Comparison of the main tectonic phases and events in the early Paleozoic evolution of some regions of the Alexander terrane and the Lachlan Fold Belt. The evolution of the Lachlan Belt is interpreted primarily from the descriptions and interpretations of Cas (1983), Veevers (1984), and Scheibner (1985). The time scale is from Palmer (1983).

similarities (appendix), provide a basis for speculations on the displacement history of the terrane. We propose a scenario in which the terrane evolved as an offshore volcanic arc during late Proterozoic(?)-Cambrian time, was involved in a regional orogenic event during the Middle Cambrian-Early Ordovician, and evolved in a volcanic arc-marginal basin environment during Ordovician-Early Silurian time. Beginning in Early Silurian time and continuing into the Early Devonian, the arc system was involved in an orogenic event which included regional deformation, metamorphism, anatectic magmatism, uplift, erosion, and perhaps extension.

We speculate that the Alexander terrane was removed from the vicinity of the Gondwana margin after or during the waning stages of this Silurian-Early Devonian orogenic activity because it did not experience the widespread Middle Devonian and younger tectonic events recorded along the margin. Extensional structures which formed prior to and perhaps after the Tabberabberan orogeny may record rifting of the Alexander terrane and other tectonic fragments from the Gondwana margin.

During Carboniferous-Permian time the terrane apparently evolved near the paleoequator, according to both paleomagnetic and paleobiogeographic data (Van der Voo et al., 1980; Ross and Ross, 1983, 1985; Mamet and Pinard, 1985). Because the terrane was apparently located near or south of the paleoequator in the eastern part of the paleoPacific basin by the Late Triassic, it must have drifted eastward across the paleo-Pacific basin between Devonian and Late Triassic time. Combined with the upper Paleozoic geologic record of the terrane, these constraints indicate that it may have moved eastward as part of a microcontinental fragment in an intraplate oceanic environment. The Alexander terrane was apparently rifted from its northeastern continuation or from rocks belonging to another tectonic fragment during Late Permian(?)Triassic time, which, as described by Gehrels and Saleeby (1985), initiated its northward migration along the eastern margin of the paleo-Pacific basin.

\section{Discussion of the Proposed Displacement History}

The displacement scenario presented above is derived primarily from our interpretations that the Alexander terrane is an exotic component in the North American Cordillera and that its early Paleozoic history most closely resembles that recorded along the paleo-Pacific margin of Gondwana. Although geologic and paleomagnetic similarities with eastern Australia have been noted, precise paleopositions of the terrane cannot be determined until more is known about other orogens that formed along the Gondwana margin and until the degree of tectonic mobility in these orogens has been assessed. The path, timing, and mechanism of its displacement across the paleo-Pacific basin are also very poorly known. The only apparently reliable constraints are that the terrane was (1) in proximity to the Gondwana margin through Silurian-earliest Devonian time, (2) near the paleoequator in a tectonically stable environment during late Paleozoic time, (3) near or south of the paleoequator in the eastern part of the paleo-Pacific basin during the Late Triassic, and (4) near its present position in the Cordillera by Late Cretaceous-early Tertiary time.

The proposed displacement scenario is offered as an alternative to hypotheses linking 


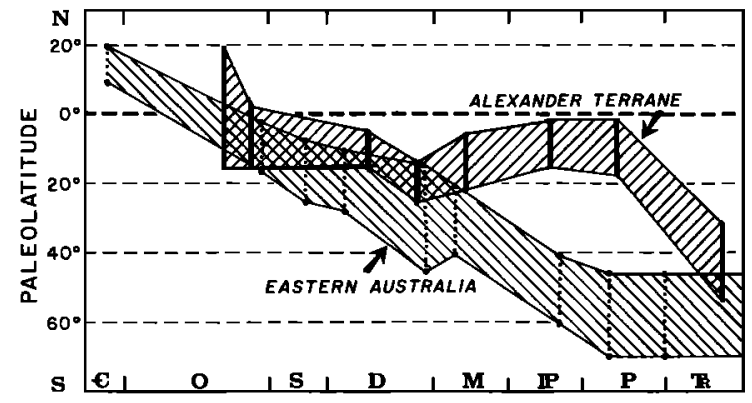

Fig. 8. Comparison of the apparent paleolatitudes of the Alexander terrane (assuming it was in the southern hemisphere) and of eastern Australia. Paleolatitudes and their uncertainties for the Alexander terrane (Van der Voo et al., 1980; Panuska and Stone, 1985; Hillhouse and Gromme, 1980) are shown with solid bars, which have been connected to yield a generalized apparent paleolatitudinal path for the Alexander terrane. The paleolatitudes for eastern Australia (dotted vertical lines) represent the paleolatitudinal range of the eastern margin of Australia on paleocontinental reconstructions by Scotese (1984). These vertical lines have been connected to yield an approximate paleolatitudinal path for eastern Australia. Note that the uncertainty in the paleolatitude of eastern Australia is not shown on this diagram and that, according to Scotese (1984), the Late Devonian paleolatitude of eastern Australia is not well constrained.

the Alexander terrane with rocks in the SierraKlamath region, which we consider unlikely, and as a specific outline which can be tested. A tested and modified displacement history for the Alexander terrane should provide critical information on the accretionary history of western North America and the evolution of the paleo-Pacific margin of Gondwana and may also lead to a method for reconstructing the movement of pre-Mesozoic oceanic plates in the paleo-Pacific basin.

\section{SUMMARY}

The Alexander terrane is a unique tectonic fragment in the North American Cordillera in that its geologic record is suprisingly long, complete, and well preserved. The Triassic and every Paleozoic epoch are represented in the terrane except for the Late Permian and perhaps the Early Cambrian. In most areas, the rocks are only slightly to moderately deformed and are not highly metamorphosed.

We suggest that the terrane evolved through three distinct tectonic phases, including late Proterozoic(?)-Cambrian through Early Devonian, Middle Devonian through Early Permian, and Late Permian(?)-Triassic. The first phase records the origin and evolution of the terrane in a volcanic arc(?) environment during late Proterozoic(?)-Cambrian time, and continued arc-type volcanism and plutonism in the southern part of the terrane during Ordovician-Early Silurian time. The arc-type activity was interrupted during the Middle Cambrian-Early Ordovician Wales orogeny and was terminated during the middle Silurianearliest Devonian Klakas orogeny. These orogenic events apparently record primarily crustal shortening, but it is not known whether they occurred in response to interplate or intraplate processes. Rocks of early Paleozoic age in the northern part of the terrane form a thick section of limestone and clastic strata that apparently have not experienced either of the two early Paleozoic disturbances.

Rocks of Middle Devonian through Permian age were deposited in tectonically stable shallow-marine environments, and they record the second phase in the evolution of the Alexander terrane. Volcanic rocks of Devonian and of Permian age occur locally, but they do not appear to have accumulated in long-lived or regionally significant magmatic systems. The third stage is recorded by deposition of Triassic volcanic and sedimentary rocks in a rift(?) environment and by a regional unconformity at the base of the Triassic section. Occurrence of the Triassic strata along the eastern margin of the terrane in SE Alaska suggests that this interpreted rifting may record detachment of the terrane from previously contiguous rocks or from another tectonic fragment.

Previous discussions of the displacement history of the Alexander terrane have focused on correlations with Paleozoic rocks in the Sierra-Klamath region of California. Our analyses of the Paleozoic geologic records of the Alexander terrane and of the SierraKlamath region suggest, however, that there are few similarities in their geologic and tectonic history. Based on a review of the geology of other early Paleozoic orogens, we raise the alternative possibility that the Alexander terrane formed and evolved along the paleo-Pacific margin of Gondwana during early Paleozoic time. The existing paleomagnetic data and, to a lesser degree, the paleobiogeographic affinities of fossil groups from the Alexander terrane are apparently consistent with this hypothesis, although some lower Paleozoic fossils in the terrane apparently have stronger affinities with other parts of the circum-Pacific region. 
We speculate further that the terrane separated from the Gondwana margin during Devonian time, perhaps through rifting, and migrated eastward across the paleo-Pacific ocean basin south of the paleoequator during late Paleozoic time. We envision the terrane as a microcontinental fragment in an intraplate oceanic environment during this time. By Late Triassic time the terrane was apparently near or south of the paleoequator in the eastern part of the paleo-Pacific basin - perhaps in association with rocks now in western South America. Northward displacement of the terrane along the eastern margin of the paleoPacific basin apparently began during or soon after Late Triassic time and continued until it was accreted during Late Cretaceous-early Tertiary time.

\section{APPENDIX: REPORTED SIMILARITIES}

BETWEEN FAUNA AND FLORA FROM THE ALEXANDER TERRANE AND FOSSIL GROUPS IN OTHER REGIONS

TRIASSIC: Bivalves - eastern part of the paleoPacific basin and near the paleoequator (Tozer, 1982); similar to fauna along the Pacific margin of South America (Newton, 1983; Silberling, 1985)

EARLY PERMIAN: Brachiopods - similar fauna occur in the Urals, southern China, eastern Alaska, the Canadian Arctic, Yugoslavia, and in a melange in central Oregon (Grant, 1971); Boreal fauna (Yancey, 1975)

Various fauna indicate a position within the paleo-Pacific basin and south of the paleoequator (Ross and Ross, 1983, 1985)

PENNSYLVANIAN: Fusulinids - similar to fauna in Japan and the Cache Creek terrane (central British Columbia) (Douglass, 1971) Conodonts - generally cosmopolitan but have affinities with midcontinent North American fauna (Savage and Barkeley, 1985)

Various fauna indicate a position within the paleo-Pacific basin and near the paleoequator (Ross and Ross, 1983, 1985)

MISSISSIPPIAN: Conodonts - western North

American affinity (Savage, 1984)

Foraminifera - both Tethyan and North

American affinities present (Mamet and Pinard, 1985; Dutro et al., 1981)

Algal microflora - cosmopolitan, but together with foraminifers they constitute a link between Eurasia and North America (Mamet and Pinard, 1985)

Various fauna indicate a position within the paleo-Pacific basin and south of the paleoequator (Ross and Ross, 1985)

LATE DEVONIAN: Brachiopods - generally
North American although some degree of isolation is indicated (Savage et al., 1978) Corals - similar to fauna in the U.S.S.R. (Tchudinova et al., 1974)

MIDDLE DEVONIAN: Conodonts - Cordilleran North American affinity (Savage, 1984); cosmopolitan (Klapper and Johnson, 1980) Corals - similar to fauna in the U.S.S.R. (Tchudinova et al., 1974)

EARLY DEVONIAN: Conodonts - similar to fauna in western North America, eastern Australia, and central Asia (Savage, 1984); one genus (Kimognathus) is known only from central Asia and eastern Australia (Savage and Gehrels, 1984)

Land plants (Baragwanatia) and graptolites similar to an occurrence in eastern Australia (Churkin et al., 1969, p. 567); similar land plants also occur in North America and Europe (L.J. Hickey, written communication, 1985)

Corals - similar to fauna in Asiatic U.S.S.R.

(Churkin et al., 1970)

Brachiopods - endemic fauna and also similar

to fauna in western North America, Europe, Australia, and northeastern U.S.S.R. (Soja, 1985)

SILURIAN: Brachiopods - similar to fauna in the eastern Urals (Kirk and Amsden, 1952) and in Nevada and the Canadian Arctic (J.G. Johnson, written communication, 1986) Conodonts - similar to fauna in the Selwyn Basin (northern Canadian Cordillera) (M. Orchard, written communication, 1986)

ORDOVICIAN: Conodonts - belong to the North Atlantic conodont province (Savage, 1984); similar to fauna in the Selwin Basin and the Kechika trough (northern Canadian Cordillera) (M. Orchard, written communication, 1986); belong to a peripheral biofacies (J.G. Johnson, written communication, 1986)

Graptolites - Pacific faunal province (C. Carter, written communication, 1986).

Acknowledgments. Our field work in SE Alaska has been supported by the U.S. Geological Survey and by research grants awarded to G.E.G. from the California Institute of Technology, the Geological Society of America, and Sigma Xi. We thank Henry C. Berg for his guidance and assistance in collecting the data summarized herein and for sharing his knowledge of the geology of SE Alaska. We also wish to express our appreciation to R.B. Blodgett, N.M. Savage, J.M. Berdan, A.J. Boucot, C. Carter, M. Churkin, J.T. Dutro, R.E. Grant, L.J. Hickey, J.G. Johnson, C.R. Newton, W.A. Oliver, M. Orchard, C.A. Ross, J.R.P. Ross, N.J. 
Silberling, and C.H. Stevens for assistance in compiling the appendix. Comments by Henry C. Berg, David A. Brew, and an anonymous reviewer improved the manuscript considerably.

\section{REFERENCES}

Berg, H. C., D. L. Jones, and D. H. Richter, Gravina-Nutzotin belt - Tectonic significance of an upper Mesozoic sedimentary and volcanic sequence in southern and southeastern Alaska, U.S. Geol. Surv. Prof. Pap., 800-D, D1-D24, 1972.

Berg, H. C., D. L. Jones, and P. J. Coney, Map showing pre-Cenozoic tectonostratigraphic terranes of southeastern Alaska and adjacent areas, U.S. Geol. Surv. Open File Rep., 78$1085,1978$.

Brew, D. A., and A. B. Ford, Preliminary reconnaissance geologic map of the Juneau, Taku River, Atlin, and part of the Skagway 1:250,000 quadrangles, southeastern Alaska, U.S. Geol. Surv. Open File Rep., 85-395, 1985.

Brew, D. A., R. A. Loney, and L. J. P. Muffler, Tectonic history of southeastern Alaska, CIM Spec. Vol., 8, 149-170, 1966.

Brew, D. A., B. R. Johnson, D. Grybeck, A. Griscom, and D. F. Barnes, Mineral resources of the Glacier Bay National Monument wilderness study area, Alaska, U.S. Geol. Surv. Open File Rep., 78-494, 1-670, 1978.

Brew, D. A., A. T. Ovenshine, S. M. Karl, and S. J. Hunt, Preliminary reconnaissance geologic map of the Petersburg and parts of the Port Alexander and Sumdum quadrangles, southeastern Alaska, U.S. Geol. Surv. Open File Rep., 84-405, 1-43, 1984.

Buddington, A. F., and T. Chapin, Geology and mineral deposits of southeastern Alaska, U.S. Geol. Surv. Bull., 800, 1-398, 1929.

Campbell, R. B., and C. J. Dodds, Geology of the southwest Kluane Lake Map-Area, Yukon Territory, Geol. Surv. Can. Open File Rep., 829, 1982a.

Campell, R. B., and C. J. Dodds, Geology of the Mount Saint Elias Map-Area, Yukon Territory, Geol. Surv. Can. Open File Rep., $830,1982 b$.

Campbell, R. B., and C. J. Dodds, Geology of the southwest Dezadeash Map-Area, Yukon Territory, Geol. Surv. Can. Open File Rep., 831, 1982c.

Campbell, R. B., and C. J. Dodds, Geology of the Tatshenshini River Map-Area, British Columbia, Geol. Surv. Can. Open File Rep., 926, 1983a.

Campbell, R. B., and C. J. Dodds, Geology of the Yakutat Map-Area, British Columbia, Geol. Surv. Can. Open File Rep., 927, 1983b.
Cas, R., A review of the paleogeographic and tectonic development of the Lachlan Fold Belt of southeastern Australia, Spec. Publ., Geol. Soc. Aust., 10, 1-104, 1983.

Churkin, M., Jr., Paleozoic marginal ocean basin-volcanic arc systems in the Cordilleran foldbelt, Spec. Publ., Soc. Econ. Paleontol. Mineral., 19, 174-192, 1974.

Churkin, M., Jr., and G. D. Eberlein, Ancient borderland terranes of the North American Cordillera: Correlation and microplate tectonics, Geol. Soc. Am. Bull., 88, 769-786, 1977.

Churkin, M., Jr., G. D. Eberlein, F. M. Heuber, and S. H. Mamay, Lower Devonian land plants from graptolitic shale in southeastern Alaska, Paleontology, 12, 559-573, 1969.

Churkin, M., Jr., H. Jaeger, and G. D. Eberlein, Lower Devonian graptolites from southeastern Alaska, Lethaia, 3, 183-202, 1970.

Cooper, R. A., and G. W. Grindley (Eds.), Late Proterozoic to Devonian sequences of southeastern Australia, Antarctica, and New Zealand and their correlation, Spec. Publ., Geol. Soc. Aust., 9, 1-103, 1982.

D'Allura, J. A., E. M. Moores, and L. Robinson, Paleozoic rocks of the northern Sierra Nevada: Their structural and paleogeographic implications, in Paleozoic Paleogeography of the Western United States, edited by J. H. Stewart, C. H. Stevens, and A. E. Fritsche, pp. 395-408, Pacific Section, Society of Economic Paleontologists and Mineralogists, Los Angeles, Calif., 1977.

Douglass, R. C., Pennsylvanian fusulinids from southeastern Alaska, U.S. Geol. Surv. Prof. Pap., 706, 1-21, 1971.

Dutro, J. T., Jr., A. K. Armstrong, R. C. Douglass, and B. L. Mamet, Carboniferous biostratigraphy, southeastern Alaska, U.S. Geol. Surv. Circ., 823-B, B94-B96, 1981.

Eberlein, G. D., and M. Churkin, Jr., Paleozoic stratigraphy in the northwest coastal area of Prince of Wales Island, southeastern Alaska, U.S. Geol. Surv. Bull., 1284, 1-67, 1970.

Eberlein, G. D., M. Churkin, Jr., C. Carter, H. C. Berg, and A. T. Ovenshine, Geology of the Craig quadrangle, Alaska, U.S. Geol. Surv. Open File Rep., 83-91, 1-28, 1983.

Engebretson, D. C., A. Cox, and R. G. Gordon, Relative motions between oceanic and continental plates in the Pacific basin, Spec. Pap., Geol. Soc. Am., 206, 1-59, 1985.

Evans, K. V., Ordovician plutonism in eastcentral Idaho: Variation on a Canadian theme, Geol. Soc. Am. Abstr. Programs, 16, 504, 1984.

Gehrels, G. E., and H. C. Berg, Geologic map of southeastern Alaska, U.S. Geol. Surv. Open File Rep., 84-886, 1-28, 1984. 
Gehrels, G. E., and J. B. Saleeby, Paleozoic geologic history of the Alexander terrane in SE Alaska, and comparisons with other orogenic belts, Geol. Soc. Am. Abstr. Programs, 16, 516, 1984.

Gehrels, G. E., and J. B. Saleeby, Constraints and speculations on the displacement and accretionary history of the AlexanderWrangellia- Peninsular superterrane, Geol. Soc. Am. Abstr. Programs, 17, 356, 1985.

Gehrels, G. E., and J. B. Saleeby, Geologic map of southern Prince of Wales Island, southeastern Alaska, U.S. Geol. Surv. Open File Rep., 86-275, 1986.

Gehrels, G. E., and J. B. Saleeby, Geology of southern Prince of Wales Island, southeastern Alaska, Geol. Soc. Am. Bull., 98, in press, 1987.

Gehrels, G. E., J. B. Saleeby, and H. C. Berg, Preliminary description of the Klakas orogeny in the southern Alexander terrane, southeastern Alaska, in Pre-Jurassic Rocks in Western North American Suspect Terranes, edited by C. H. Stevens, pp. 131-141, Pacific Section, Society of Economic Paleontologists and Mineralogists, Los Angeles, Calif., 1983.

Gehrels, G. E., C. J. Dodds, and R. B. Campbell, Upper Triassic rocks of the Alexander terrane, SE Alaska \& the Saint Elias Mountains of B.C. and Yukon, Geol. Soc. Am. Abstr. Programs, 18, 109, 1986.

Gehrels, G. E., J. B. Saleeby, and H. C. Berg, Geology of Annette, Gravina, and Duke islands, southeastern Alaska, Can. J. Earth Sci., 24, in press, 1987.

Girty, G. H., and M. S. Wardlaw, Was the Alexander terrane a source of feldspathic sandstones in the Shoo Fly Complex, Sierra Nevada, California?, Geology, 12, 339-342, 1984.

Grant, R. E., Taxonomy and autecology of two Arctic Permian rhynchonelloid brachiopods, Smithson. Inst. Contrib. Paleontol., 3, 313335, 1971.

Hanson, R. E, J. B. Saleeby, and R. A. Schweikert, Composite Devonian island arc batholith in the northern Sierra Nevada, California, Geol. Soc. Am. Bull., 98, in press, 1987.

Harwood, D. S., Stratigraphy of upper Paleozoic volcanic rocks and regional unconformities in part of the northern Sierra Nevada, California, Geol. Soc. Am. Bull., 94, 413-422, 1983.

Herreid, Gordon, T. K. Bundtzen, and D. L. Turner, Geology and geochemistry of the Craig A-2 quadrangle and vicinity, Prince of Wales Island, southeastern Alaska, Geol. Rep., Alaska Div. Geol. Geophys. Surv., 48, 1$49,1978$.
Hillhouse, J. W., and C. S. Gromme, Paleomagnetism of the Triassic Hound Island Volcanics, Alexander terrane, southeastern Alaska, J. Geophys. Res., 85, 2594-2602, 1980.

Hudson, T., G. Plafker, and K. Dixon, Horizontal offset history of the Chatham Strait fault, U.S. Geol. Surv. Circ., 844, 128132, 1981.

Irwin, W. P., Review of Paleozoic rocks of the Klamath Mountains, in Paleozoic Paleogeography of the Western United States, edited by J. H. Stewart, C. H. Stevens, and A. E. Fritsche, pp. 441-454, Pacific Section, Society of Economic Paleontologists and Mineralogists, Los Angeles, Calif., 1977.

Irwin, W. P., Age and tectonics of plutonic belts in accreted terranes of the Klamath Mountains, California and Oregon, in Tectonostratigraphic Terranes of the CircumPacific Region, edited by D. G. Howell, pp. 187-200, Circum-Pacific Council for Energy and Mineral Resources, Houston, Texas, 1985.

Jones, D. L., W. P. Irwin, and A. T. Ovenshine, Southeastern Alaska -- A displaced continental fragment?, U.S. Geol. Surv. Prof. Pap., 800-B, B211-B217, 1972.

Kirk, E., and T. W. Amsden, Upper Silurian brachiopods from southeastern Alaska, U.S. Geol. Surv. Prof. Pap., 233-C, C53-C66, 1952.

Klapper, G., and J. G. Johnson, Endemism and dispersal of Devonian conodonts, $\mathrm{J}$. Paleontol., 54, 400-455, 1980.

Lathram, E. H., J. S. Pomeroy, H. C. Berg, and R. A. Loney, Reconnaissance geology of Admiralty Island, Alaska, U.S. Geol. Surv. Bull., 1181-R, 1-48, 1965.

Lindsley-Griffin, N., and J. R. Griffin, The Trinity terrane: An early Paleozoic microplate assemblage, in Pre-Jurassic Rocks in Western North American Suspect Terranes, edited by C. H. Stevens, pp. 63-76, Pacific Section, Society of Economic Paleontologists and Mineralogists, Los Angeles, Calif., 1983.

Loney, R. A., D. A. Brew, L. J. P. Muffler, and J. S. Pomeroy, Reconnaissance geology of Chichagof, Baranof, and Kruzof islands, southeastern Alaska, U.S. Geol. Surv. Prof. Pap., 792, 1-105, 1975.

MacIntyre, D. G., Geology of the AlsekTatshenshini Rivers area, B. Columbia Min. Energy, Mines, Pet. Resour. Pap., 1984-1, 173-184, 1984.

MacKevett, E. M., Jr., Geologic map of the MacCarthy quadrangle, Alaska, U.S. Geol. Surv. Misc. Invest. Map, I-1032, 1978.

Mamet, B. L., and S. Pinard, 9 Carboniferous Algae from the Peratrovich Formation, southeastern Alaska, in Paleoalgology: Contemporary Research and Applications, 
edited by D. F. Toomey and M. H. Nitecki, pp. 91-100, Springer-Verlag, New York, 1985.

Monger, J. W. H., and H. C. Berg, Lithotectonic terrane map of western Canada and southeastern Alaska, U.S. Geol. Surv. Open File Rep., 84-523, B1-B31, 1984.

Monger, J. W. H., and C. A. Ross, Distribution of Fusulinaceans in the western Canadian Cordillera, Can. J. Earth Sci., 8, 259-278, 1971.

Monger, J. W. H., J. G. Souther, and H. Gabrielse, Evolution of the Canadian Cordillera: A plate tectonic model, Am. J. Sci., 272, 577-602, 1972.

Muffler, L. J. P., Stratigraphy of the Keku Islets and neighboring parts of Kuiu and Kupreanof islands, southeastern Alaska, U.S. Geol. Surv. Bull., 1241-C, 1-52, 1967.

Newton, C. R., Paleozoogeographic affinities of Norian bivalves from the Wrangellian, Peninsular and Alexander terranes, western North America, in Pre-Jurassic Rocks in Western North American Suspect Terranes, edited by C. H. Stevens, pp. 37-48, Pacific Section, Society of Economic Paleontologists and Mineralogists, Los Angeles, Calif., 1983.

Ovenshine, A. T., Tidal origin of parts of the Karheen Formation (Lower Devonian), southeastern Alaska, in Tidal Deposits, a Casebook of Recent Examples and Fossil Counterparts, edited by R. N. Ginsburg, pp. 127-133, Springer-Verlag, New York, 1975.

Ovenshine, A. T., and G. D. Webster, Age and stratigraphy of the Heceta Limestone in northern Sea Otter Sound, southeastern Alaska, U.S. Geol. Surv. Prof. Pap., 700-C, C170-C 174, 1970.

Ovenshine, A. T., G. D. Eberlein, and M. Churkin, Jr., Paleotectonic significance of a Silurian-Devonian clastic wedge, southeastern Alaska, Geol. Soc. Am. Abstr. Programs, 1, $50,1969$.

Palmer, A. R., The Decade of North American Geology Time Scale, Geology, 11, 503-504, 1983.

Panuska, B. C., and D. B. Stone, Latitudinal motion of the Wrangellia and Alexander terranes and the southern Alaska superterrane, in Tectonostratigraphic Terranes of the Circum-Pacific Region, edited by D. G. Howell, pp. 109-120, CircumPacific Council for Energy and Mineral Resources, Houston, Texas, 1985.

Potter, A. W., P. E. Hotz, and D. M. Rohr, Stratigraphy and inferred tectonic framework of lower Paleozoic rocks in the eastern Klamath Mountains, northern California, in Paleozoic Paleogeography of the Western United States, edited by J. H. Stewart, C. H.
Stevens, and A. E. Fritsche, pp. 421-440, Pacific Section, Society of Economic Paleontologists and Mineralogists, Los Angeles, Calif., 1977.

Ross, C. A., and J. R. P. Ross, Late Paleozoic accreted terranes of western North America, in Pre-Jurassic Rocks in Western North American Suspect Terranes, edited by C. H. Stevens, pp. 7-22, Pacific Section, Society of Economic Paleontologists and Mineralogists, Los Angeles, Calif., 1983.

Ross, C. A., and J. R. P. Ross, Carboniferous and Early Permian biogeography, Geology, 13, 27-30, 1985.

Saleeby, J. B., J. L. Hannah, and R. J. Varga, Isotopic age constraints on middle Paleozoic deformation in the northern Sierra Nevada, California, Geology, in press, 1987.

Savage, N. M., Provincial affinities of conodont faunas from the Alexander terrane, southeastern Alaska, Geol. Soc. Am. Abstr. Programs, 16, 644-645, 1984.

Savage, N. M., and S. J. Barkeley, Early to middle Pennsylvanian conodonts from the Klawak Formation and the Ladrones Limestone, southeastern Alaska, J. Paleontology, 59, 1451-1475, 1985.

Savage, N. M., and G. E. Gehrels, Early Devonian conodonts from Prince of Wales Island, southeastern Alaska, Can. J. Earth Sci., 21, 1415-1425, 1984.

Savage, N. M., G. D. Eberlein, and Michael Churkin, Jr., Upper Devonian Brachiopods from the Upper Devonian Port Refugio Formation, Suemez Island, southeastern Alaska, J. Paleontology, 52, 370-393, 1978.

Scheibner, E., Suspect terranes in the Tasman Fold Belt System, eastern Australia, in Tectonostratigraphic Terranes of the CircumPacific Region, edited by D. G. Howell, pp. 493-514, Circum-Pacific Council for Energy and Mineral Resources, Houston, Texas, 1985.

Schuchert, C., Sites and nature of the North American geosynclines, Geol. Soc. Am. Bull., 34, 151-230, 1923.

Schweikert, R. A., Early Mesozoic rifting and fragmentation of the Cordilleran orogen in the western U.S.A., Nature, 260, 586-591, 1976.

Schweikert, R. A., and W. S. Snyder, Paleozoic plate tectonics of the Sierra Nevada and adjacent regions, in The Geotectonic Development of California, edited by W. G. Ernst, pp. 182-210, Prentice-Hall, Englewood Cliffs, N. J., 1981.

Scotese, C. R., An introduction to this volume: Paleozoic paleomagnetism and the assembly of Pangea, in Plate Reconstruction From Paleozoic Paleomagnetism, Geodyn., Ser., vol. 12, edited by R. Van der Voo et al., pp. 110, AGU, Washington, D.C., 1984. 
Scotese, C., R. K. Bambach, C. Barton, R. Van der Voo, and A. Ziegler, Paleozoic base maps, J. Geol., 87, 217-278, 1979.

Silberling, N. J., Biogeographic significance of the Upper Triassic bivalve Monotis in Circum-Pacific accreted terranes, in Tectonostratigraphic Terranes of the CircumPacific Region, edited by D. G. Howell, pp. 63-70, Circum-Pacific Council for Energy and Mineral Resources, Houston, Texas, 1985.

Soja, C. M., A new look at an old fauna: Kindle's Kasaan Island locality (southeastern U.S.A.) reexamined, paper presented at 1st International Congress on Brachiopods, Univ. de Bretagne Occidental, Brest, 85, 1985.

Tchudinova, I. I., M. Churkin, Jr., and G. D. Eberlein, Devonian Syringoporid corals from southeastern Alaska, J. Paleontol., 48, 124$134,1974$.

Tipper, H. W., G. J. Woodsworth, and H. Gabrielse, Tectonic assemblage map of the Canadian Cordillera and adjacent parts of the United States of America, Geol. Surv. Can. Map, 1505A, 1981.

Tozer, E. T., Marine Triassic faunas of North America: Their significance for assessing plate and terrane movements, Geol. Rundsch., 71, 1077-1104, 1982.

Turner, D. L., G. Herreid, and T. K. Bundtzen, Geochronology of southern Prince of Wales island, Alaska, Geol. Rep., Alaska Div. Geol. Geophys. Surv., 55, 11-16, 1977.

Van der Voo, R., M. Jones, C. S. Gromme, G. D. Eberlein, and M. Churkin, Jr., Paleozoic paleomagnetism and northward drift of the
Alexander terrane, southeastern Alaska, J. Geophy. Res., 85, 5281-5296, 1980.

Varga, R. J., and E. M. Moores, Age, origin, and significance of an unconformity that predates island-arc volcanism in the northern Sierra Nevada, Geology, 9, 512-518, 1981.

Veevers, J. J. (Ed.), Phanerozoic Earth History of Australia, 418 pp., Clarendon, Oxford, 1984.

Wilson, J. T., Static or mobile earth, the current scientific revolution, Proc. Am. Philos. Soc., 112, 309-320, 1968.

Woodsworth, G. J., and M. J. Orchard, Upper Paleozoic to lower Mesozoic strata and their conodonts, western Coast plutonic complex, British Columbia, Can. J. Earth Sci., 22, 1329-1344, 1985.

Yancey, T. E., Permian marine biotic provinces in North America, J. Paleontol., 49, 758-766, 1975.

Yorath, C. J., and R. L. Chase, Tectonic history of the Queen Charlotte Islands and adjacent areas - A model, Can. J. Earth Sci., 18, 1717-1739, 1981.

G. E. Gehrels, Department of Geosciences, University of Arizona, Tucson, AZ 85721.

J. B. Saleeby, Division of Geological and Planetary Sciences, California Institute of Technology, Pasadena, CA 91125.

(Received June 10, 1986;

revised November 25, 1986;

accepted November 26, 1986.) 